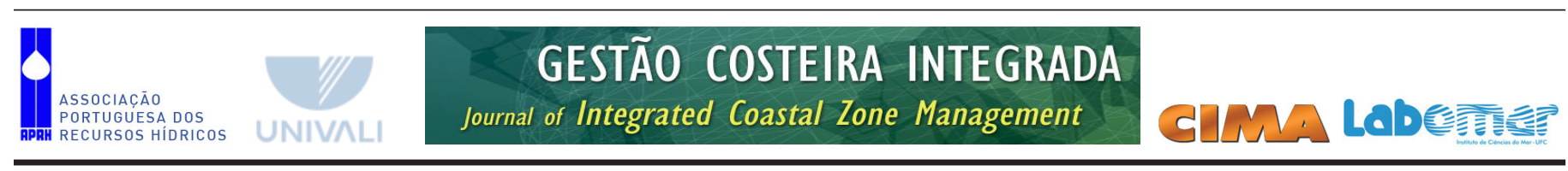

http://www.aprh.pt/rgci/pdf/rgci-473_Fernandes.pdf | DOI:10.5894/rgci473

\title{
Applying an integrated landscape characterization and evaluation tool to small islands (Pico, Azores, Portugal) *
}

\author{
Aplicação de uma caracterização integrada da paisagem e de uma ferramenta de \\ avaliação a pequenas ilhas (Pico, Açores, Portugal)
}

\author{
J.P. Fernandes ${ }^{1,2}$, N. Guiomar ${ }^{\circledR, 1,2}$, M. Freire ${ }^{2,3}$, A. Gil $^{4}$
}

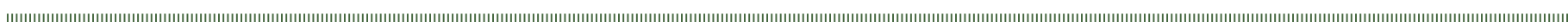

\begin{abstract}
Each landscape is determined and can be characterised by two types of environmental factors: stable biophysical characteristics and manageable land use patterns. The consideration of both these characterisation domains allows the definition of a homogeneous system of reference (the stable characteristics) with which every possible land use pattern can be compared through the use of common evaluation algorithms. The Integrated Landscape Assessment (ILA) concept builds a framework for data retrieval and evaluation processing that maximizes the following advantages: through the use of a stable reference system, it allows the comparative simulation of different land use scenarios, as well as the permanent availability of the same reference system, independently from the intensity of land use changes throughout the years. It also allows the use of different evaluation algorithms according to different evaluation contexts or paradigms, without having to repeat or adapt the characterisation process.

The present paper illustrates the basic concepts on which ILA is based and developed as well as its application to ecological planning and systematic conservation planning in the Pico Island (Azores Archipelago).
\end{abstract}

Keywords: Systematic conservation planning, integrated landscape assessment, GIS, Macaronesia.

\section{RESUMO}

Cada território é determinado e pode ser caracterizado por dois tipos de factores ambientais: características biofísicas estáveis e padrōes de uso do solo susceptiveis de gestão. A consideração destes dois dominios de caracterização permite a definição de um sistema de referência homogéneo (as características estáveis), relativamente ao qual cada possivel padrão de ocupação do solo pode ser comparado através do uso de algoritmos de avaliaçáo comuns. $O$ conceito de Análise Integrada da Paisagem (ILA) corresponde a um quadro de referenciação de dados de caracterização e avaliação e de realização de procedimentos de avaliação. Com o recurso ao ILA e através do uso de um sistema de referência espacial estável, é possivel a simulação comparativa de diferentes cenários de ocupação do território, bem como a permanente disponibilidade do mesmo sistema de referência, independentemente das variaçóes mais ou menos intensas dos padróes de ocupação do território ao longo dos anos. Permite também o uso de diferentes algoritmos de avaliação de acordo com diferentes contextos ou paradigmas de avaliação, sem ter de repetir ou de adaptar o processo de caracterização territorial.

O presente artigo ilustra os conceitos em que o ILA se baseia e desenvolve, bem como a sua aplicação ao planeamento ecológico e ao planeamento sistemático de conservação da natureza na ilha do Pico (Arquipélago dos Açores).

Palavras Chave: Planeamento sistemático de conservação, avaliação integrada da paisagem, GIS, Macaronésia.

@-Corresponding author: Guiomar <nunogui@uevora.pt>

1 - ICAAM - Instituto de Ciências Agrícolas e Ambientais Mediterrânicas, Universidade de Évora, Portugal.

2 - Departamento de Paisagem, Ambiente e Ordenamento, Universidade de Évora

3 - e-GEO Centro de Estudos de Geografia e Planeamento Regional

4 - Azorean Biodiversity Group, CITA-A, Department of Biology, University of the Azores 


\section{INTRODUCTION}

Small islands are ipso facto largely coastal entities (Saffache $\&$ Angelelli, 2010). They constitute a particular example of integration through space and time of multiple natural, social and economic functions. This integration is materialized in a set of land use systems and social structures adapted to the particular natural constraints and resources framed by the available technologies. Each structure tries to find the best conjunctural solution to the feasibility equation, balancing labor and other investments with the different products and alternative sources, in order to maximize the desired landscape functions.

Nevertheless, in the case of the North Atlantic Archipelagos of Canaries, Madeira and Azores, this integration is only several hundred years old and interrelates two completely different evolutionary processes. On one side the natural island ecosystems that evolved undisturbed for millennia, determining, because of their isolation, particular geo-morpho-climatology, and bio-, anemo- and hydro-choric processes, singular communities with unique character, particular patterns of biodiversity and high degree of endemism (Borges et al., 2000; Duarte et al., 2008; Borges \& Hortal, 2009; Bastos et al., 2012). On the other side, human communities arrived to these islands in the last millennia or few hundred years, and quickly introduced their particular land uses, cultures and imported plants and animals, replacing or destroying many habitats and species and facilitating the invasion by alien species (Martins, 1993; Silva \& Tavares, 1997; Yanes et al., 1997; de Nascimento et al., 2009; Silveira \& Dentinho, 2010; Triantis et al., 2010; Fernández-Palacios et al., 2011; Connor et al., 2012).

These manifold interactions generated very diverse landscape functions and processes that integrate the way the landscape respond to the human needs and factors of disturbance, as well as the way in which it ensures the functions corresponding to the needs of all other components of the island ecosystem. These interactions built a complex multifunctional system whose management poses particular challenges, given the need to ensure a sustainable development of the human communities, and simultaneously ensuring, not only the preservation of the existing ecological values, but also the recovery and eventual restoration of threatened or locally destroyed ones.

To these challenges one must still consider the foreseeable disturbances associated with climate change (Fonseca et al., 2006; Robertson et al. 2011), as well as by urban and infrastructural development (often associated with tourism), that destroy or drastically change varied areas of habitat, mainly along the coast, but also frequently, in areas with a particular scenic character or morphologic particularities.

These two factors of threat must be considered with particular attention, their possible consequences in small islands almost ecologically isolated with exception of human carried propagules, which can determine, in a short term, a dramatic change in the island ecology. These issues and problems have to be faced taking into consideration that in humanized insular environments, the identification of values and threats as well as its valuation and the definition of management objects and targets in what regards nature conservation, have to take into consideration criteria and perspectives (as well as systems of values) different (to say the least) of those adopted in mainland systems.

Another critical issue is the unique character of each island implying the need to adopt for each one individually adapted planning and management (Wong et al., 2005). Therefore, in these unique and differently but normally strongly humanized environments, it is crucial the availability of characterization and evaluation frameworks able to characterize the existing land resources and processes, as well as the way they are affected or allocated at any moment and land use context. Simultaneously, such a characterization and evaluation framework must be able to allow the development of land use scenarios and the evaluation of their consequences in terms of the sustainability of the ecological values and functions of each island.

In order to be able to fulfil these tasks, the ILA (Integrated Landscape Ecological Analysis) (Fernandes et al., 2006) model has been developed. ILA is a framework for environmental characterization and evaluation. Its objectives are to build a coherent characterization and evaluation framework for landscape ecological studies, and to allow, within this framework, all types of expert knowledge or models to be operated on a coherent working background.

The ILA model is based on the following basic ideas:

- Each landscape is determined and can be characterized by two types of environmental factors:

- Stable biophysical characteristics and related functions and processes;

- Manageable land use patterns and related functions and processes.

- The consideration of the above mentioned levels of characterization allows the definition of a homogeneous system of reference (the stable characteristics) to which every possible land use pattern can be compared through the use of common modelling and evaluation algorithms.

ILA is, consequently, a framework for data and processes characterization and evaluation, where the only requirement is the availability of a stable geographical reference base that can be qualified with the same set of indicators or descriptors as the system to be evaluated.

This implies that every geographical land use, habitat or ecological structural arrangement can be described by a set of indicators or other evaluation tools, susceptible of being applied, at the same time, to a given stable geographical or ecological reference system. in order to determine the variation of these indicators or evaluation descriptors. As a result, for each type of case study, a particular geometry and representation scale, as well as a set of elements and functions to be represented, must be identified according to the definition of the research targets. In order, for example, to be able to simulate different sets of management criteria, eventually different representation geometries will have to be simultaneously considered and included in the research objectives.

The main methodological advantage of ILA is the fact that, on the basis of its concept, are geometrical and 
functional descriptions of the landscape and a conceptual framework where given processes or characteristics can be analysed, simulated or evaluated in a consistent and coherent way, allowing, namely, the combination and application of both economic and ecological models. It allows also the combination of different working scales through the aggregation of scale-compatible units or objects in higher hierarchical units. These processes can be entirely developed in the frame of common geographic information systems and geostatistical frameworks.

\section{BUILDING AN INFORMATION FRAMEWORK FOR SYSTEMATIC CONSERVATION PLANNING IN AN ISLAND CONTEXT}

\subsection{Conceptual framework}

Landscape characterization in the frame of planning and management processes considers the need to differentiate the different domains or information layers which, when integrated, build the representation of the character of a landscape at a given moment (Fernandes, 1993).

This approach presents, nevertheless, important constraints, because it doesn't integrate the processes and interactions that occur in the different layers and between them. Additionally it does not take into consideration the time dimension and the evolutionary processes intrinsic to the nature of the landscape itself. It is therefore necessary to complement and develop this characterization model, in order to include these processes, as well as making it able to represent and operate the temporal evolution processes.

Such characterization model has to consider in its basic assumptions, that one must distinguish between the layer of the stable resources and the layer(s) of the resource allocation, according to different uses (human or natural) or planning alternatives and scenarios (Fernandes, 2000a). This distinction derives from the fact that the stable resources and structural processes correspond to the intrinsic framework of each landscape, including, not only the availability of resources, but also temporal factors like release rates (e.g. natural geological weathering and nutrient or soil elements release rate). This resource layer interacts with the circumstantial layers by conditioning their characteristics and dynamic patterns as well as the levels of resource availability.

It is based on these concepts and perspectives, and on the consideration that different disturbances determine distinct hierarchical types of influences and perturbations on the different landscape elements, that the Integrated Landscape Assessment approach (ILA) was developed (Fernandes, 2000b). As a consequence, the ILA model includes at least two conceptual working layers:

- A circumstantial layer corresponding to the present conjunctural state of the landscape depicting the present factors of resource allocation.

- A stable potential layer depicting the stable characteristics of each site and allowing the identification of use constraints or potentials (e.g. available resources, their availability rates or spatial process paths and patterns).
These two layers correspond, conceptually, to the resource baseline and its evolution trend and to a given land use situation (present or planning scenario of resource allocation) allowing the evaluation of the resulting evolution trends, in the classical sense of impact evaluation (Figure 1).

Each layer will display the structural arrangement of landscape units and associated ecotopes. As a result we obtain an information system where every geographical land use or habitat can be described by a set of indicators or other evaluation tools, that can be applied both to the present landscape as well as to the stable reference geographical or ecological system, in order to determine the variation of these indicators or evaluations descriptors (Fernandes et al., 2006).

With such an instrument it is consequently possible to evaluate the reversibility or irreversibility of given disturbances, and the positive or negative sustainability of each land use in each landscape unit. We can also identify the nature (resource or disturbance) of landscape corridors or other connectivity paths, the effective degree of complementarity between land units and the real variation on the degree of fragmentation (Fernandes, 2000a, 2000b).

When analysing nature conservation issues, this approach of a sinecological character, must be complemented by an autoecological characterisation of target species, groups of species and habitats. This characterisation will include, for example, the habitat demands for these species and can be associated with the optimum curves for each species or groups of species or habitats, allowing the identification of the degree of fulfilment of the ecological optimum by the prevailing condition in each land unit. Such information or models will allow, for example, the evaluation of the degree of stress that a given target species is supporting in its present habitat (e.g. due to habitat reduction, fragmentation or loss of habitat complementarity) and, therefore, the evaluation of its resilience relative to external disturbance such as land use changes or natural environmental oscillations.

The use of the ILA model at structural and functional levels allows the use of a large variety of tools like:

- Comparison of landscape metrics (Leitão \& Ahern, 2002; Kelly et al., 2011) between the reference and the circumstantial characterisation layers;

- Qualitative evaluation of the stable or circumstantial character of landscape elements (like matrix, patches or corridors) or characteristics (like fragmentation, connectivity or complementarity) (e.g. Watts \& Handley, 2010; Martín-Martín et al., 2013);

- Landscape or habitat connectivity or connectedness modelling as well as target animal movements, using for example percolation or cost-distance models (Richard \& Armstrong, 2010; Etherington \& Holland, 2013);

- Evaluation of management scenarios according to different sets of valuation criteria (Fernandes, 2000a; Castellazzi et al., 2010; Bryan et al., 2011).

\subsection{Application to the universe of small islands}

The development of characterization models able to support ecosystem-based management processes in small 


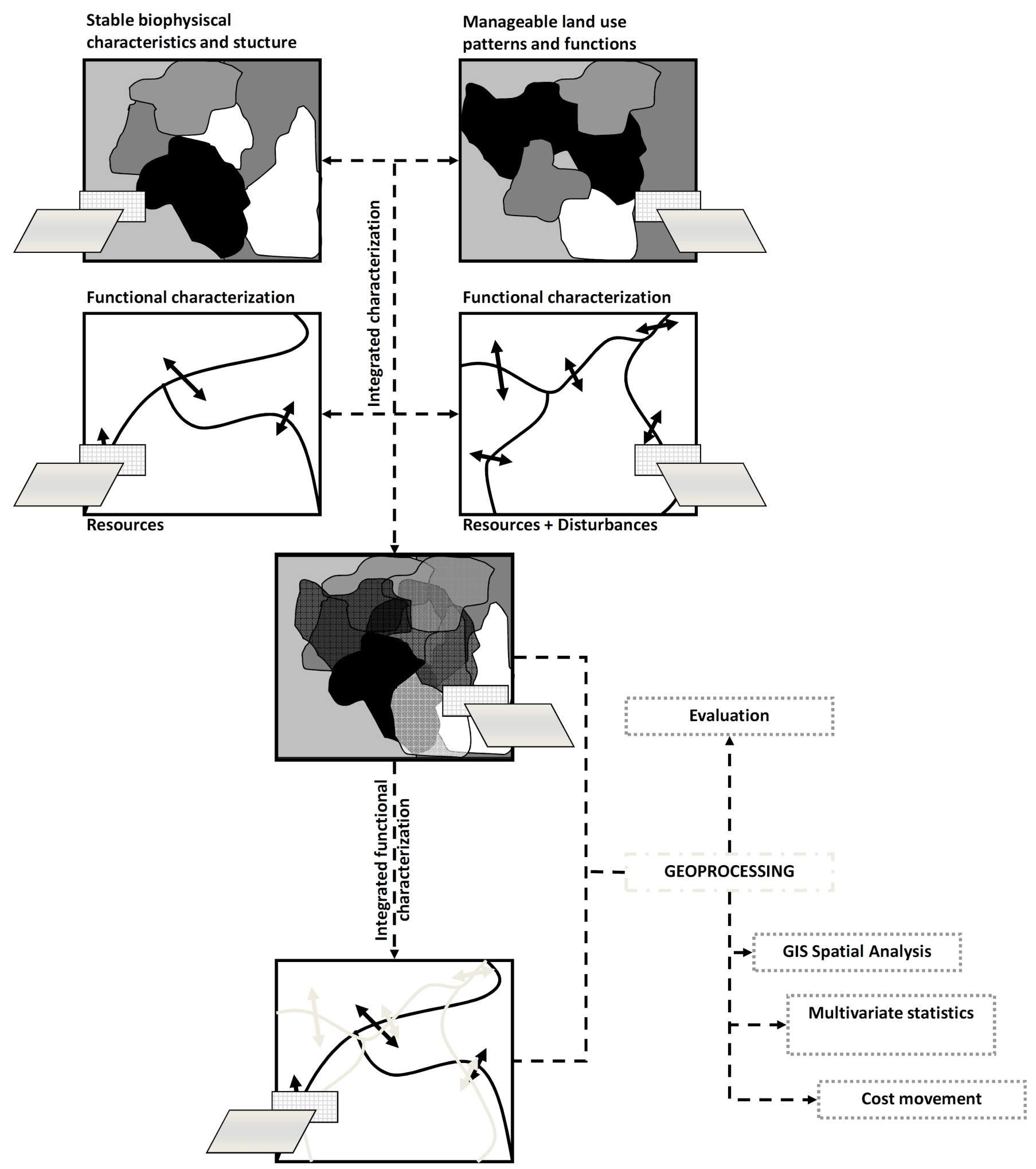

Figure 1. General structure of the ILA model (Fernandes et al., 2006).

Figura 1. Estrutura geral do modelo ILA (Fernandes et al., 2006). 
islands face several difficulties related, not only, with data availability, but also with the particularities of small islands environments. The main differences between small islands and mainland ecosystems are, as already referred, the fact that, while in continental systems the pedologic and bioclimatic factors are dominant, determining the ecological zoning, in islands systems, these factors appear conditioned in particular ways, due to the restricted geographic space of each island, what makes particularly complex the development of a reference model for these systems.

Let's consider several works conducted in different Atlantic islands (Diniz \& Matos, 1986; Cruz, 1994; Diniz \& Matos, 1999; Capelo, 2004; del-Arco et al., 2006, 2009). One can verify that the master lines of the ecological zoning in these islands are primarily referred to morphological factors (slope position, local morphology and aspect) that will influence the critical climatic factors (water and temperature) in terms of direct exposure or shelter, in terms of altitudinal zoning or in the exposure to the different types of winds with different moisture content (influencing rainfall and evapotranspiration), as well as to the indirect precipitation associated with the formation of stable cloud belts at given altitudes.

Only marginally, and detectable at detailed scales, are the influence of the soil and other forms of substrate noticeable. The main types of such features in the case of the Santiago Island (Cape Verde) are water courses and drainage lines, open valleys, beaches, arid areas and wetlands (Diniz \& Matos, 1986). In the case of El Hierro (Canaries), there are important areas of not zonal vegetation associated with particular geological occurrences, rocky substrates, areas subject to salt influence and sandy subtracts (del-Arco et al., 2006). Finally, in Madeira there are important areas of non zonal vegetation associated with riparian areas, rocky substrates, salinity gradient influence and sandy subtract (Cruz, 1994). It is important to stress that all considered Atlantic islands are of a volcanic origin that doesn't allow a wide variation of soil types, geochemistry and related ecological characteristics.

These examples, although not exhaustive and systematic, illustrate quite well, what must be the main guidelines for the construction of a biophysical system of reference for insular environments. Thus, these lines will have to integrate the main determinant ecological (phytogeographic) factors as well as local factors that determine differences in the distribution of plant communities (Stephenson, 1990; Huston, 1999; Wright et al., 2003; Zelený et al., 2010; Bui, 2013; Costa et al., 2013; Dorman et al., 2013; Laliberté et al., 2013; Moeslund et al., 2013).

All these factors (resources) must be considered in their present (and not potential) form, because the purpose of these characterization approach is that it must express the present reality of the resources and not their hypothetical evolution in a much longer time frame than that of the planning and management process. This approach correspond consequently, in its essence, to the conceptual matrix developed by Diniz \& Matos (1986) that allowed them to perform, for the entire Archipelagos of Cape Verde and São Tomé e Príncipe and also vast areas in Angola (Diniz \& Matos, 1998), a ample set of evaluation procedures for planning and management of agriculture, but that can directly be also used for nature conservation and other purposes (e.g. Cienciala et al., 2013).

ILA is of particular utility in this context, because it allows the consistent consideration, comparison and evaluation of the same geographical object in different forms (e.g. land use or natural habitats spatial allocation) or according to different evaluation criteria (e.g. naturalness or adaptation to given target species or habitats). This consistency derives, as stated, from the definition of an independent object of reference (e.g. ecological reference units) that can be characterized with the same set of indicators as all scenarios or land use alternatives, and support evaluation algorithms adapted to the different selected evaluation criteria.

Critical for the development of all the algorithms based in target habitat or target species criteria, is the availability of detailed data on the autoecology of these particular species or the synecology of these habitats. An example of such databases is, for the Azores archipelago, the Azorean Biodiversity Portal (Borges et al., 2010).

Particularly important is the determination of criteria for the definition of minimal viable populations (Shaffer, 1981; Gilpin \& Soulé, 1986; Flather et al., 2011) and the identification of critical factors affecting these criteria, such as, among others, habitat area, fragmentation, patchiness, edge/core relation, (e.g. Saunders et al., 1991; Lamberson et al., 1994; Tscharntke et al., 2002; Borges \& Hortal, 2009; Weigelt \& Kreft, 2013).

The second set of data includes the interaction between land uses and natural values, and implies the creation of a detailed database on each type of patch, in which, at least the associated natural values, are identified together with the historical and present factors determining their characteristics and conditioning the existence of these values. Of particular importance is the clear identification of the native or alien nature of these values, and, in the last case, their positive or negative feedbacks over time for autochthon values.

The third set of data is critical for the future conduction of the management processes. This is mainly due to the fact that it must bring together economic and ecological factors within their social context.

Thus, the first question to assess when developing planning and management instruments, is the way in which the different stakeholders (e.g. farmers) make their management decisions. This is of the utmost importance for example in the frame of conservation planning and policymaking to search and identify the factors that potentiate a positive involvement instead of the classical limitation (prohibition) approach of many conservation policies. There are domains where it is possible to find a replacement for former damaging practices or other types of trade-offs. The example of the development in the Azores islands of a leisure "industry" around whale watching and diving that built an alternative to the former activity of whale hunting is a particular good example of this process.

But at the level of much of the stakeholders (farmers and fishermen) the alternative is not so easy, because of the difficulty in identifying and developing non-commodity outputs that compensate certain restrictions derived from the needs for a systematic conservation and ecosystem-based 
management. This is exactly the level where the ability to evaluate and simulate alternative management approaches using a single integrated tool, will be able, not only to define policies, but also to allow the involvement of all stakeholders in the definition of these alternatives, and particularly in their implementation. This involvement is potentiated by the availability of comprehensive information and results of modeling (including their basic assumptions).

This is achieved, not only trough the characteristics of the ILA framework as a basis for this modeling process, but also because it builds a very malleable and maneuverable instrument to display and discuss the different scenarios and criteria. One can, therefore, implement multifunctional management systems, integrating all factors in a clearly defined geographical framework. The only way to ensure the sustainability of the processes of sound and assumed governance, involves strong and reliable forms of contracting and accounting, ensuring a comprehensive clarification of all the responsibilities involved, the assumptions and criteria on which the policies and decisions are based, and the robustness and soundness of the accountability processes (Gil et al., 2011a, 2011b).

In an island environment, with strictly limited resources, consensual managementapproaches are of critical importance. As a consequence, the ability to sample all information in a coherent framework where all evaluation procedures can be lead in a reproducible way with a comprehensive reference system, allows an active involvement of all stakeholders in the development of the best solutions for each site and moment and the permanent reevaluation of these solutions.

\subsection{Building the characterization system}

As previously stated when describing the ILA model, the first step for its implementation is the characterization of the reference layer. This layer must be defined in such a way that it represents, with the best possible detail, the stable biophysical characteristics of the area. Therefore, its quality, accuracy and volume of integrated information depend from the available information and its quality and detail.

The geographical object that will build the basic structure of this layer can be designated as "ecological reference unit" (ERU) in the sense that it integrates all determinant stable ecological factors occurring in the study area. As previously stated, these factors correspond basically to the following list:

- Main determinant ecological (phytogeographic) factors:

- Bioclimatology (generally related to elevation and slope aspect);

- Macro-relief, conditioning slope exposition but also the predominant dynamic processes such as landslides, valley breezes, Foehn effects, hydrologic retention, evapotranspiration and indirect precipitation (fog or clouds);

- Substrate, determining, between many other factors, nutrients, water availability and thermal balances;

- Local factors:

○ Micro-relief;
- Soils and substrates;

- Water availability;

○ Chemical constraint factors (e.g. nutrients, salts, toxicity).

Its selection derives from the fact that the ERUs are primarily focused on areal characteristics and express mainly ecological factors determinant of the development of vegetation and the differentiation of vegetation communities.

Particular relevant factors for the fauna and that are independent from the present vegetation, must also be taken into consideration (e.g. cliffs, presence of water, rockiness). Associated with this layer of geographical elements, other layers must be built, characterizing the dynamic processes occurring in that area: among others, hydrology, macro- and micro-climatology, erosion and sedimentation patterns.

Of particular importance is the need to ensure that all these characterization layers and databases have common descriptors as it would be the case if applied to the present landscape. Only in this way can they be compared, and evaluation procedures conducted, using this reference layer as the reference for all evaluation processes. Vegetation proved to be a very adequate "common language" to fulfill this function.

In effect it showed to be useful, in most circumstances, to include in the data describing each ERU, whenever possible, the most probable vegetation communities susceptible of naturally occurring in these units. The reason for this usefulness derives from the fact that many valuation variables are easily applied to vegetation communities (and equivalent land uses), allowing a wider set of evaluation procedures and modeling possibilities.

The second domain of characterization is the present land use, where it is critical to adopt a classification system able to represent the land uses classes, and their main characteristics such as density or structural diversity. To this purpose, it is necessary to proceed the biotope or land use cartography in such a way as to ensure an adequate inventory of their nature, value(s), stress factors, conflicts, disturbances or other particular factors affecting the characteristics or functions of the site and its use or vegetation (Ichter et al. 2014).

Also noteworthy in this cartographic and data sampling process, is the need to identify and map all particular elements with ecological, socio-cultural or other significance, in order to have a complete sampling, not only of the macro habitat structure, but also from microhabitats and particular elements of special cultural significance.

\section{APPLICATION IN THE PICO ISLAND (AZORES)}

\subsection{Study area}

The Azores is an isolated North Atlantic archipelago (Figure 2a), formed by nine main islands and several small islets and seamounts located along the Mid-Atlantic Ridge (Feraud et al., 1980), approximately between the coordinates $37^{\circ}$ to $40^{\circ} \mathrm{N}$ latitude and $25^{\circ}$ to $31^{\circ} \mathrm{W}$ longitude and distributed from West-Northwest (WNW) to East-Southeast (ESE). Over $1600 \mathrm{~km}$ from Portuguese mainland (and 1900 $\mathrm{km}$ from Newfoundland), the Azorean islands (Figure 2b) extend for about $615 \mathrm{~km}$ and are divided into three groups: 
the western group (Flores and Corvo); the central group (Faial, Pico, S. Jorge, Terceira and Graciosa); and the eastern group (S. Miguel and S. Maria, plus the Formigas islets). All islands are volcanic of recent origin, having arisen along ocean-floor fracture zones where the North American, Eurasian, and African tectonic plates meet at a triplejunction (Ferreira, 2005; Azevedo \& Ferreira, 2006 Calado et al., 2013). According to Azevedo \& Ferreira (2006) the western group is situated entirely on the North American Plate and the other two groups are within a transition zone named Azorean micro-plate between the Eurasian and African Plates.

The Azores are the youngest archipelago in the Macaronesian region (Fernández-Palacios et al., 2011). The oldest rocks in the archipelago are found on Santa Maria Island (8.12 Myr B.P.) while Pico is the youngest island of the archipelago (0.25 Myr B.P.) (Abdel-Monem et al. 1975; Feraud et al. 1980; Azevedo et al., 1991; Nunes 1999; Azevedo \& Ferreira, 2006).

This study was conducted in the Pico Island (Figure 2c) which is the second largest island of the archipelago with $447.74 \mathrm{~km}^{2}$. Presents an oval shape, elongated in the E-W direction, trending along ca. $42 \mathrm{~km}$ long and ca. $15.2 \mathrm{~km}$ wide (maximum values) (Cancela d'Abreu et al., 2005).

\subsection{Building the resource information layer}

The sources of information for Pico are very diversified but have important limitations in critical variables like soil and vegetation maps, as well as deficiencies in their cartographic quality.

\subsubsection{Biophysical Information}

\section{Geology}

The Island of Pico, through its morphology, expresses remarkably the effects of volcano-tectonic structures that are in its origin (Nunes, 1999; Madeira \& Silveira, 2003; Cruz et al., 2006; França et al., 2006; Dias et al., 2007). Three different areas can be distinguished on the island (Madeira, 1998; Nunes, 1999; Madeira \& Silveira, 2003; França et al., 2006; Dias et al., 2007): the older volcano (Topo volcano), a central type shield volcano located in the middle-south of the island, is composed of ankaramitic and basaltic lava flows and is partially dismantled by landslides, displaced by faulting and covered by younger volcanism; an intermediate volcanostratigraphic unit, which comprises several alignments of basaltic spatter cones and related lava flows along WNW-ESE fault; and finally the youngest unit of the island is the Madalena Volcanic Complex, which can be structurally divided into two sub-units, the East fissural zone which is composed of several alignments of cinder and
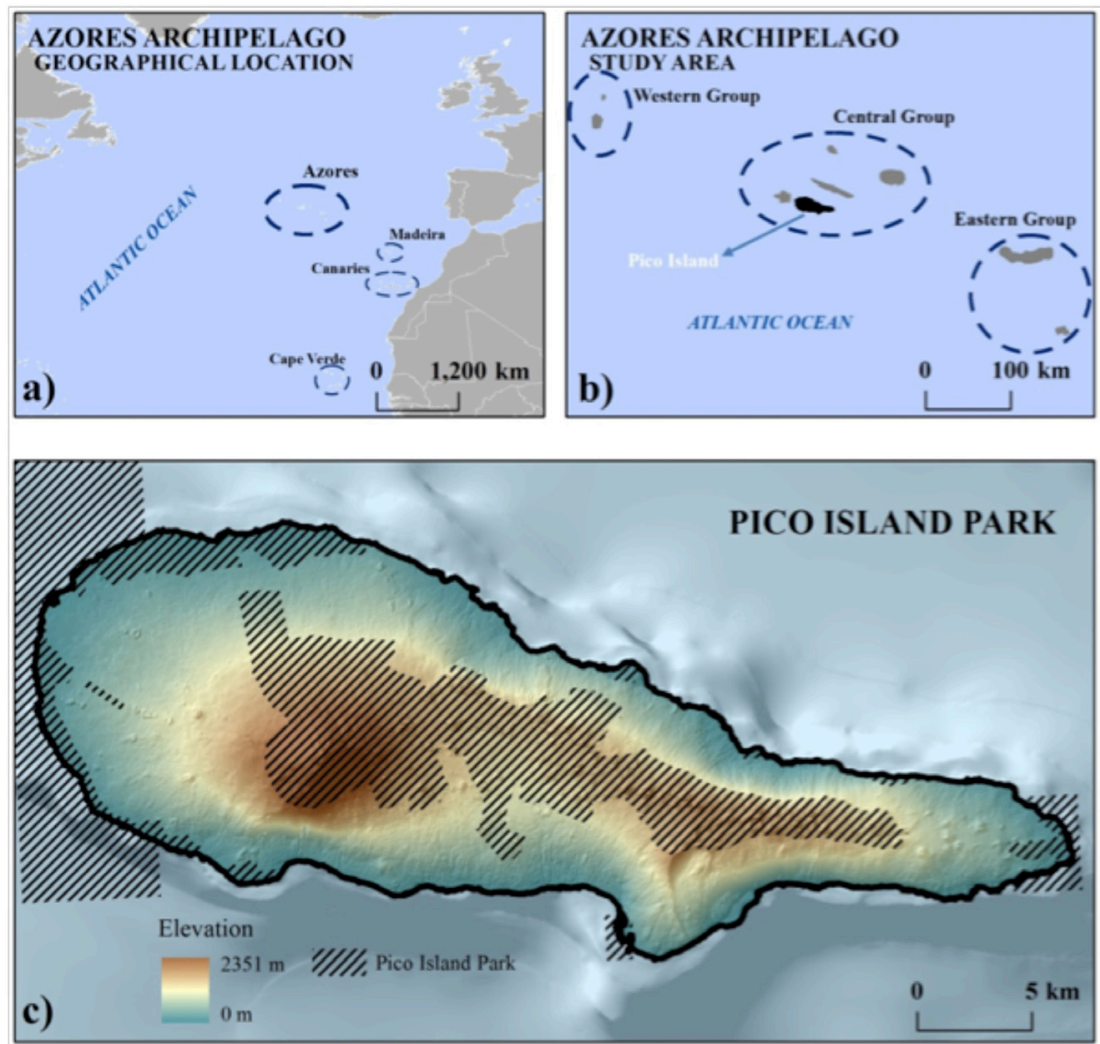

Figure 2. Study area.

Figura 2. Área de Estudo. 
spatter cones and related lava flows, and the strato-volcano of Pico displaying a pit crater on its summit and straddling the fissural structure at its western end. Over these three units one can observe recent volcanic occurrences (1562-64, 1718 and 1720), that correspond to the different "Mistérios" formations.

\section{Soils}

Soils are generally young andisols, developed from pyroclastic materials under humid and mesic conditions (Pinheiro et al., 1998; Auxtero \& Madeira, 2009). Soils differ essentially on the P sorption and adsorption capacity (Auxtero et al., 2007) due to the presence of colloidal constituents which have been observed in soils with andic properties (Madeira et al., 2007). Given that a soil map of the Pico Island was unavailable, the Soil Quality Map (Pinheiro et al., 1987) was used, presenting a classification (I to VII) of the soils suitability for agriculture and forestry, together with the indication of particular limiting factors like risk of erosion or drenching.

The analysis of the map allows us to observe the absence of soils belonging to class I and II (arable soil apt for permanent use) and only limited areas of classes III, IV and III+IV (arable soils with occasional use). Analyzing the soil maps and related data, it is possible to verify the extreme poverty of the soils of the Pico Island (only 2.2\% are arable soil without limitations), and the overwhelming percentage of soils with extreme limitations and only aptitude for natural pastures or forest or that should be preserved as natural reserve because they cannot sustain any economical use (56.6 $\%)$. Considering the subclasses displaying soil limitations, it is possible to verify that $64 \%$ present limitations for the good development of roots and $27 \%$ present erosion risks. These results show an island with a very limited potential for agriculture and only a limited potential for pasture. Due to all these limitations, the large majority of the island should be preferably reserved for natural vegetation (aggregation of classes VI and VII and their combinations).

\section{Digital Elevation Model and derived information}

The data on altimetry was used to build a Digital Elevation Model through the Topo to Raster module (ArcGIS $10^{\mathrm{TM}}$ ) which is based on the algorithm developed by Hutchinson (1989). This approach uses an iterative finite difference interpolation technique and it is a discretized version of thin plate splines (Wahba, 1990). Slopes were computed according to the Horn's method (Horn, 1981) and hydrologic analysis followed the eight-direction flow model (D8), presented by Jenson \& Domingue (1988). The characterization of the drainage system is of critical importance for management, in particular when considering that this are the paths followed by contamination and also the watersheds that ensure the existence and evolution of lakes, ponds, wetlands and mires, as well as their possible contamination or eutrophication. Therefore, each hydrological basin that showed to be endorheic was identified as a potential area for flow accumulation, information that was later compared with the soil quality map in order to identify the wet or flooded soils, which were than combined with the previous map, in order to assess its correction. It also allowed the identification of other areas with interest in terms of preservation, improvement and restoration of wetlands and habitats associated with wet or (temporarily or permanently) drenched soils. Pico volcano is the highest altitude in the Azores $(2351 \mathrm{~m})$, and slopes range from 0 to $61.45^{\circ}$.

\section{Climate}

We used data from the CIELO model to characterize the main climatic elements (Azevedo et al., 1998, 1999a, 1999b). The climate of the island is temperate oceanic with low annual temperature amplitudes, a regular rainfall distribution along the year and high relative humidity. Rainfall varies strongly with altitude from $1000-1900$ on the lower $100 \mathrm{~m}$, to more than $4000 \mathrm{~mm}$ above $700 \mathrm{~m}$. The geographical distribution of the rainfall shows a small deviation to the North. Despite its regular distribution during the year, still has some monthly variation, with maximum values in January-February and a minimum in July. Its monthly distribution shows that the winter months are the ones with the most rainfall. The indirect precipitation associated with fog and clouds is very important particularly between 180 and $700 \mathrm{~m}$. There is also snowfall mainly above $2000 \mathrm{~m}$. Moisture is also an important characteristic averaging around $80 \%$ along the year. It tends to augment with altitude, and presents a clear influence from the morphology, which can be associated with fog and mainly with the stationary clouds between 180 and $700 \mathrm{~m}$. The temperature amplitude is very small, varying in Madalena from around $13^{\circ} \mathrm{C}-14^{\circ} \mathrm{C}$ in January and February to $22^{\circ} \mathrm{C}$ $23^{\circ} \mathrm{C}$ in July and August, for an average year temperature of $17,4^{\circ} \mathrm{C}$. The winds blow predominantly from SW.

\section{Flora and vegetation}

From a chorological perspective, the Azores archipelago is included in the Macaronesian region (Fernández-Palacios \& Andersson, 2000; Vanderpoorten et al., 2007) which includes very characteristic vegetation structures with a high number of endemic taxa (superior to the expected for insular regions with their characteristics). It is also relevant because this is an area of refuge of wet subtropical vegetation formation (Laurisilvae) that built the Mediterranean basin vegetation during the Tethyan-Tertiary period (Sjögren, 2000; Dias 2001; Vargas, 2007; Rodríguez-Sánchez \& Arroyo, 2008; de Nascimento et al., 2009; Rodríguez-Sánchez et al., 2009; Schirone et al., 2010; Fernández-Palacios et al., 2011; Nogué et al., 2013). This fact, according to some authors (e.g. Sjögren, 2000), is proved by the existence of remnants of the Laurisilvae (like the presence of Laurus azorica in some areas of the littoral of Morocco and in the SW of Portugal mainland (Monchique mountain).

In Azores, 947 vascular plant species are registered, from which only $7.2 \%$ are endemic taxa (Borges et al., 2010). However, a large number correspond to exotic species resulting from accidental or voluntary introduction after the colonization of the islands. Since the settlement in the $15^{\text {th }}$ century, vegetation has changed significantly essentially for cereal crops, pasture and forestry, being currently affected by the invasive behavior demonstrated by some of the introduced species (Furtado, 1984; Martins, 1993; Silva \& 
Tavares, 1997; Silva \& Smith, 2006; Lourenço et al., 2011; Schaefer et al., 2011; Costa et al., 2012; Gil et al., 2013).

The Pico Island, from a phytocenotic perspective presents, in the context of the Azores archipelago, the highest plant diversity, due to its altitude $(2345 \mathrm{~m})$ and the small human population of the island, determining a relative low disturbance intensity. Its main vegetation types are the following (C.S. Cruz, 2013 pers. comm.):

- In the coastal area communities with Euphorbia azorica, Crithmum maritimum, Juncus acutus, Festuca petreae, Cynodon dactylon, Plantago coronopus, Lotus subbiflorus. Solidago sempervirens, Campanula vidalii, Daucus carota subsp. maritimus, Spergularia azorica, Polypogon monspeliensis, Frankenia pulverulenta, etc. can be found;

- In the lower altitudes up to $600-700 \mathrm{~m}$, forest or bush formations dominated by Myrica faya, Erica azorica, Laurus azorica, Frangula azorica, Ilex perado subsp. azorica, Viburnum tinus subsp. subcordatum, Picconia azorica, Myrsine africana, Rubus ulmifolius, Hedera helix subsp. canariensis, Smilax divaricata can be found;
- At altitudes between 500 and $1800 \mathrm{~m}$, forests of Laurus azorica. Juniperus brevifolia, Frangula azorica, Daphne laureola, Euphorbia stygiana, Prunus lusitanica subsp. azorica, Rubus hochstetterotum, Hedera helix subsp. canariensis, Vaccinium cylindraceum occur;

- Above $1700 \mathrm{~m}$, predominate shrub lands with Calluna vulgaris, Daboecia azorica and Thymus caespititius;

- In the water courses one can find essentially Laurus azorica, and Hedera helix subsp. canariensis.

\subsubsection{The land use information}

An updated GIS-based map is essential to aid environmental planning of future land cover of the casestudy area (Santos \& Gomes de Oliveira, 2013). The information on the land use of the Pico Island used was the Land Use Map (2008) produced by the University of Azores (Figure 3, Moreira, 2013).

The main features that can be observed are the very limited urban occupation, restricted almost only to the heads of the municipalities (Madalena, Lajes do Pico and São Roque) and the rest of the area is almost only occupied by pasture, natural vegetation (mainly Erica azorica and Myrica

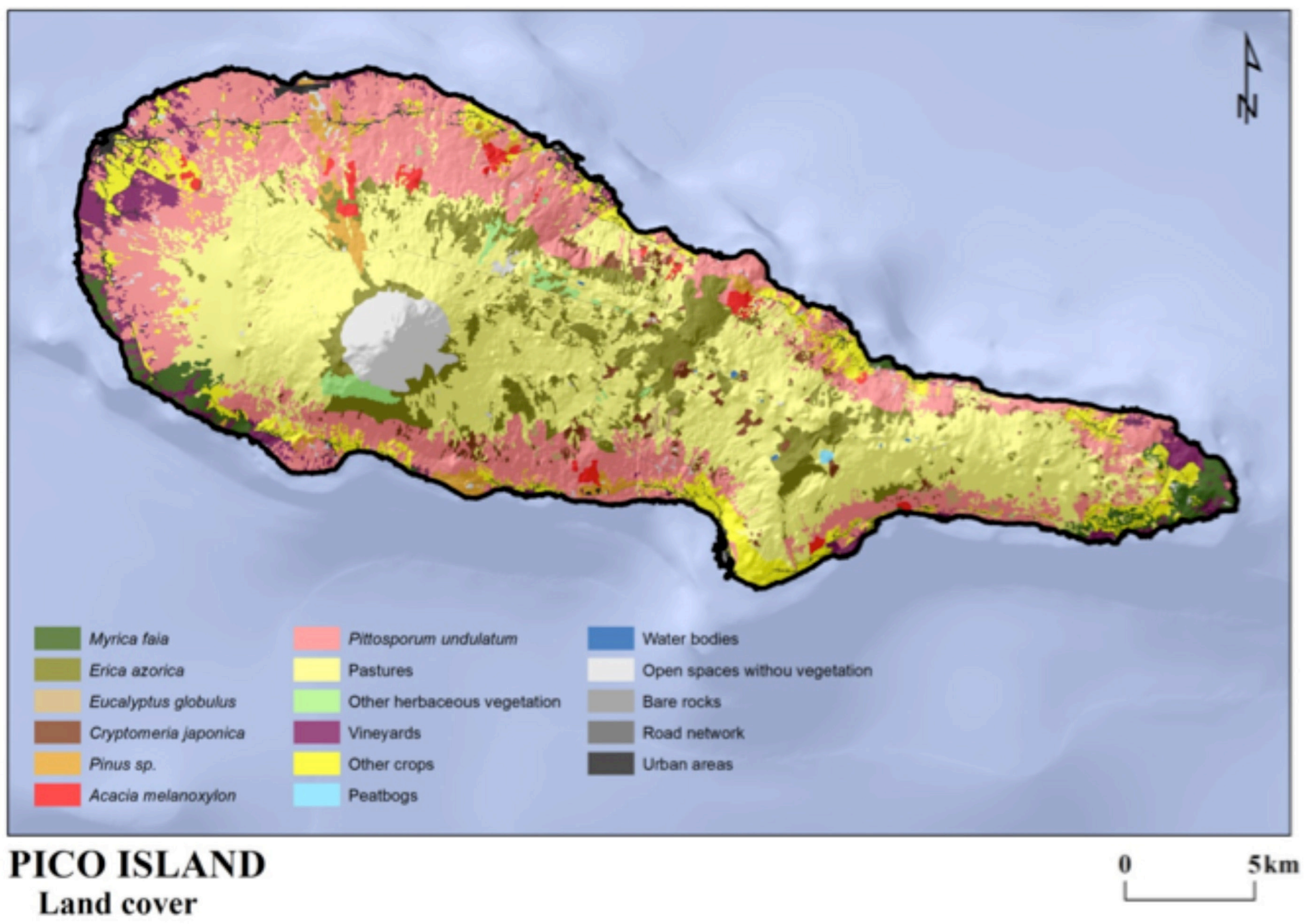

Figure 3. Land use map (2008) of Pico Island (Moreira, 2013) .

Figura 3. Carta de Ocupação do solo (2008) da Ilha do Pico (Moreira, 2013). 
faya) and invading alien vegetation (mainly Pittosporum undulatum), as well as areas of traditional vineyards that build the World Heritage cultural Landscape of the Pico Island Vineyard Culture. Most of the island presents low levels of disturbance and use intensity, except along the peripheral littoral road, with the development of $2^{\text {nd }}$ residence houses and some touristic infra-structures.

The land use map uses a very limited legend mainly focused in economic activities and providing poor information on natural formations, leading, inclusively, to some misinterpretation or even errors. One example is the classification of most of the Pico Mountain as "naked soil". The class "other herbaceous and bush vegetation" is also very general and imprecise. This lack of precision derives from the fact that these maps have been mainly produced through orthophotomaps photo-interpretation and have a working scale that doesn't allow more detailed classifications. This situation limits its ability to display elements occupying small areas or situations of combined uses. For example, there are large areas classified as Pittosporum undulatum woodland that still have important percentages of occupation by Myrica faya, and present a different significance for example, for the identification of priority management areas (in this case for the control of invasive species and the recovery of the "Faial Forest").

When comparing the agricultural use (predominantly pasture) with the soil quality map, it is possible to verify that a large percentage of the agricultural activities are located in soils with none or almost no potential for that kind of land use. Further analysis on the scarce agricultural resources of the island, stresses the need for a very careful management of the apparent areas of conflict (areas with extreme limitations and potential only for natural vegetation occupied with pastures). This can be acceptable, even in areas of high erosion risks, if the pastures and mainly the grazing intensity, is managed in the sense of the protection of the soil, and the development of a more diverse mosaic with, for example, the inclusion (or restoration) of natural thickets in the most endangered or fragile areas.

Nevertheless, the areas more susceptible to erosion are mainly located around the Pico Mountain, where there are only marginal fringes of pasture and in a large area in the eastern half of the island, in areas with a limited agricultural potential (mainly only natural pasture). This is not a critical situation, because well managed livestock grazing, together with the adequate management of the pasture vegetation, can be very effective in preventing erosion (Ammer et al. 1986).

\subsubsection{The reference information layer - Ecological reference units (ERU)}

As stated above, any characterization and evaluation process needs to have a stable comprehensive reference system, to which any item can be compared and any evaluation can be referred. In the case of geographic and land use systems, the concept of land unit (Zonneveld, 1989) is used referred to the stable biophysical variables (like geology, soil, climate, morphology, position) and expressed in different ways, namely using the natural vegetation corresponding to these stable ecological characteristics.
It was therefore in this context, that the ecological reference units (ERU) were defined, considering the geological zoning of the island, the morphology, the soil potential productivity (Pico Island Soil Quality Map), the climate zoning (considering rainfall, moisture, prevailing winds, indirect precipitation associated to cloud belts), morphology, internal drainage areas and respective watersheds as well as gully-similar water courses. 87 ERU were identified (Figure 4) and their main characteristics listed in Table 2 (see Appendix 1). The selection of the thresholds for variables like rainfall, moisture, prevailing winds or elevation was made considering their importance in the occurrence of distinct types of natural vegetation (interpreted from Dias, 2001; Dias et al., 2005).

These ERU build the main referential for the modeling and evaluation procedures. They try to reflect, in the best way possible, according to the available biophysical data, the main ecological characteristics occurring in the island. Their boundaries must be considered as having low precision, due to the fact that, for the definition of some boundaries, climatic isolines where used as a result of the absence, for example, of natural vegetation map, that would show more correct boundaries. Micro-habitats like small volcanic craters, wet soils, small mires, rocky areas are not necessarily represented for the same reason: low availability and poor reliability of the available information.

Given the fact that these units where built based on the combination of the above mentioned factors, expressing the classic concept of land unit first proposed by Zonneveld (1989), there is permanently the possibility, given the availability of better information, of correcting the ERU map, without invalidating the analytical process and the way the scenarios are built.

The analysis of the characteristics of the different ERU apparently points to a very diversified ecology, although, when analyzing with more detail the variation of these characteristics it is possible to conclude that generally, we have a altitudinal differentiation due to climatic variability, some variation between the northern and southern sides due to the prevailing winds and some variability associated with the geological substrata and the presence of drenched soils originating wetlands, lakes and mires.

In this context, we cannot speak of a high internal or diversity (the geology is homogeneous and the morphology relatively regular), but there is an important micro-structural diversity associated with small resource patches that, together with the altitudinal zoning, contribute to a relative high potential biodiversity.

\subsection{The use of ILA in the valuation and evaluation processes}

The process of valuation is critical for the scenario building and assessment procedures. Therefore, it is crucial to clarify the criteria adopted to attribute values to the different data and objects.

The context of the present study is the development of systematic conservation planning and ecosystem-based management practices in the context of small islands, ensuring the existence of open systems of governance 

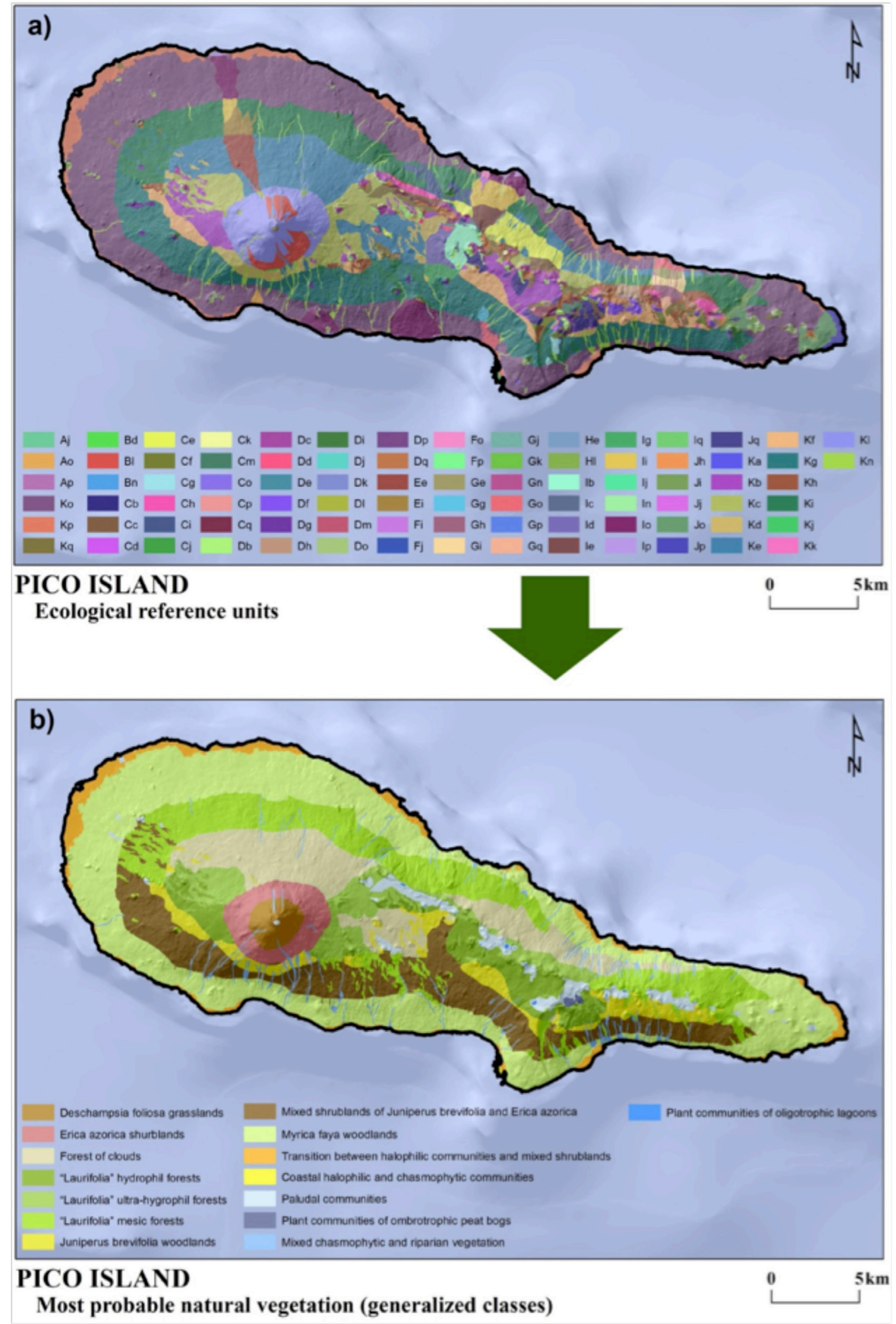

Figure 4. Ecological reference units a), and most probable natural vegetation (generalized classes from Table 2 included in Appendix 1) b).

Figure 4. Unidades ecológicas de referência a), e vegetação natural associada mais provável (classes generalizadas a partir da Tabela 2 incluida no Apêndice 1) b). 
involving an effective participation of all stakeholders. Consequently, there are two main valuation criteria to be simultaneously considered:

- Present and potential conservation value, representing the interest for the preservation and promotion of nature, natural functionality and biodiversity value;

- Societal value, including current potential economic and welfare value.

These evaluation procedures (Figures 5 and 6) were conducted, in the case of the conservation and nature protection value, considering the following estimated qualitative characteristics of each land unit (union of land use and ERU): rarity of the vegetation communities, biodiversity (intrinsic and structural), unique character of the vegetation communities, resilience, degree of threat, and naturalness.

The estimation of the relative economic value of the present land use was performed based on a qualitative combination of the average economic value of each type of land use, corrected according to soil quality and added to the socio-cultural value perceived by the islanders. This perception is still focused in the predominant value of pasture land (main income source and additionally wine producing areas. Urban expansion for 2 nd housing, although growing in importance, is still marginal in terms of income source.

Both these criteria (land productivity and subjective perception by the islanders) are not absolute as the simple consideration of the figures illustrates, showing how large are the areas occupied by pasture that have no adequate soil productivity for that land, use and that can even be degraded through erosion if the pasture management and the grazing intensity are not adequately preformed. So, considering the present land use as corresponding directly to high values when these land uses have an important economic significance, is clearly inappropriate, although it must always be taken into account that it still builds the base of subsistence for an important number of families and of the global economy of the island, and expresses the perception based on which the islanders base their benefit expectations.

In this sense, the consideration of the value of the agricultural areas or areas of potential expansion, must take into account a factor of devaluation corresponding to the situations where land productivity is too low, or the risks of land degradation associated with incorrectly managed grazing, high. Obviously, if these risks are avoided by an adequate use, an immediate revaluation of the parcel must occur.

Another example of how the context must be taken into account when attributing a value to a certain parcel for a given land use, is the case of real estate (for second housing or tourism). The first factor that must be taken into account and that is already considered in the PROTA - Regional Territorial Plan (DROTRH, 2008), are the costs of building infrastructures (namely water supply and wastewater disposal and treatment) which must be incorporated in the parcel cost, in order to avoid socialization of the cost and privatization of profits. Other important factors are, for example, the way in which a certain construction affects landscape and aesthetical values, devaluating neighbor or even far away parcels, or adding value to these parcels, situation where compensation should be in order. This process of reevaluation is of particular importance on an island with a particularly high touristic potential, based mainly in its landscape aesthetical value. Therefore, the
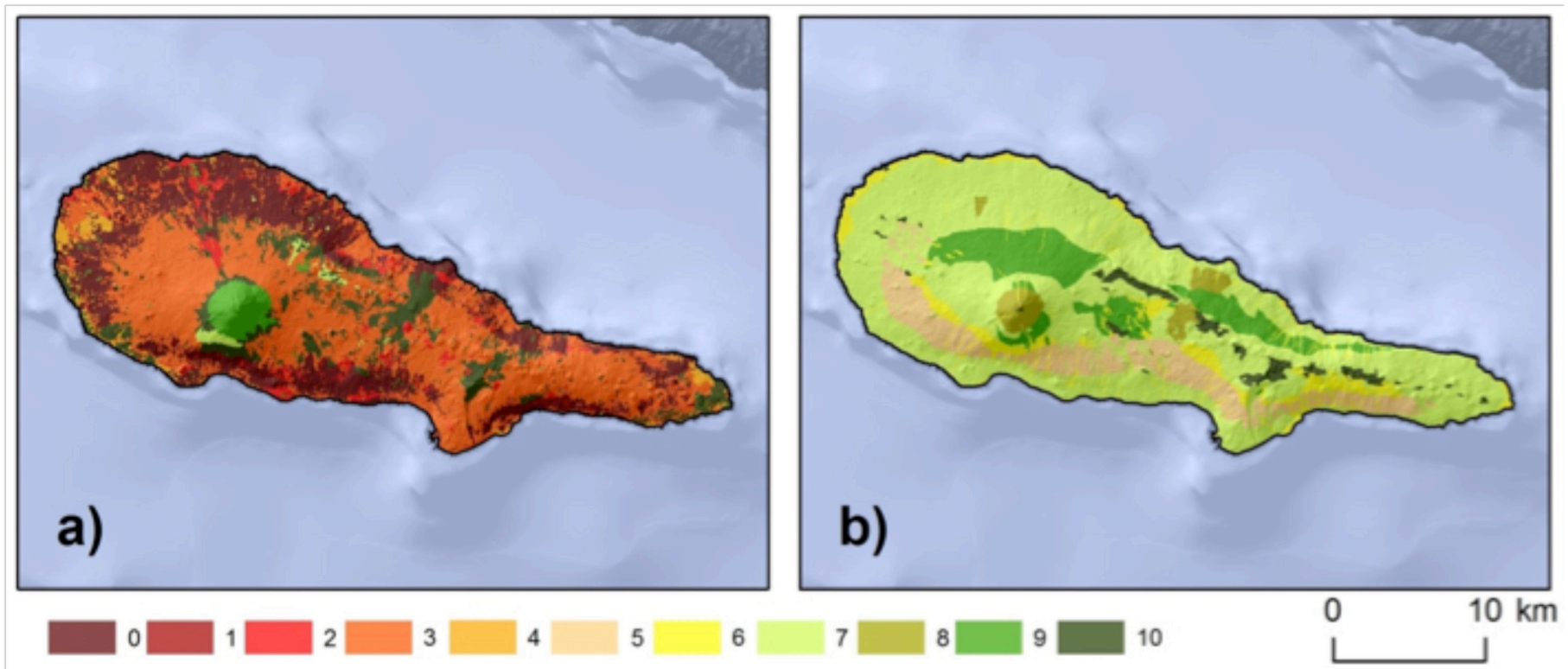

Figure 5. Qualitative estimation of the present conservation value of the present land use a), and qualitative estimation of the present conservation of the natural vegetation susceptible of occurring in the absence of disturbances b) (10 max).

Figura 5. Estimativa qualitativa do valor de conservação do quadro actual de ocupação do solo a), e estimativa qualitativa do valor de conservação da vegetação natural susceptivel de ocorrer na ausência de perturbaçóes b) (10 max). 


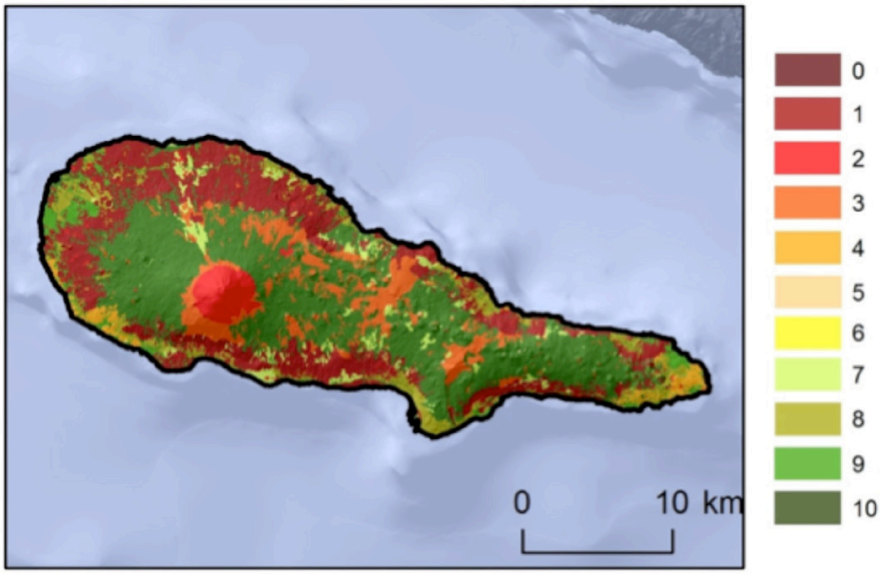

Figure 6. Qualitative estimation of the relative economic value of the present land use (10 max). Due to lack of precise information, the potential value of the coastal areas for second housing and touristic development is not included.

Figura 6. Estimativa qualitativa do valor económico relativo do quadro actual de ocupaçấo do solo (10 max). Devido à carência de informação mais detalhada, o valor potencial das zonas costeiras para habitação secundária e desenvolvimento turístico não foi incluido.

global touristic development of the island, depends of an adequate management of that landscape. Given that this management is performed by others than the touristic operators, the way the entire landscape is managed must be integrated, and all land managers (mainly farmers) must be brought together and compensated for this integrated and concerted management. This process should not be solely understood as a conservation management in the sense of preserving the present landscape as it is, but that must also take into account all added value resulting from the recovery of degraded areas, areas infested by invasive alien plant species and especially, recovery of the natural vegetation.

The ERU also allow a comparison between the reference situation and the present situation allowing the identification (within the limits of the valuation criteria) of areas of value gains or losses. Figure 7 illustrates the degree of loss of Conservation Value and Protection Value, computed by associating the conservation value with the degree of threat of each formation.

It is clear to observe that the areas without value losses (negative values) correspond to natural vegetation, while areas with positive values correspond to areas strongly infested or with a completely alloctonous vegetation.

It is important to stress that the valuation of the present land use is subject to divergence in criteria. For example, the biodiversity of the Pittosporum undulatum areas should be considered null or very low or, should it be taken into consideration that these Pittosporum undulatum communities still include an important number of native species (e.g. Myrica faya)? This second criteria is important, in the sense that it must be taken into consideration, because the eradication of Pittosporum undulatum must not correspond to the total destruction of the infested areas covered by this species, but solely to the removal of the alien species and the promotion of the remaining native ones.

The valuation of the conservation value poses still other types of problems, as is the case when the present conjunctural value of one type of vegetation formation, can correspond to situations with different levels of degradation or proximity to the natural conditions. For example, some areas of Erica azorica can correspond to pioneer or initial stages of a re-naturalization succession, whereas in other areas, it corresponds to the natural community of that particular area. Therefore, the simple fact of having an area with Erica azorica cannot be equally valued, but must take into consideration different levels of value: it is a natural plant community, but on one site one must support its evolution and eventual replacement by another community, while on the other site this is the target community.

Another problem when considering the valuation of conservation variables is their conservation status. There are different forms of classification of conservation value:

- Belonging to the Natura 2000 Network, where the quality and boundaries result from the present values existing in that area;

- Belonging to any of the conservation figures included in the Natural Park, where the boundaries were defined with nature conservation political considerations, that do not correspond necessarily with existing potential values (nevertheless one must take into account that all Natura 2000 areas are integrated in the Natural Park, what does not invalidate the different criteria for boundary definition and value assessment).

- A third type of conservation area could be eventually added, corresponding to areas fulfilling the NATURE 2000 criteria, but occupying small areas that didn't allow it's classification at the European level, but could be implemented at the island level.

While the first case (and third hypothetical case) represents an existing value and an obligation to preserve and promote it, the second case does not correspond necessarily to high value areas or represent all potential value areas. It constitutes primarily an administrative instrument aimed at the protection and promotion of conservation values.

In this context, the value associated with the conservation status must be primarily based in the existence of the value, and take into consideration the eventuality that many micro- or meso-structures or objects, do not fulfill the scale conditions of the Natura 2000 classification and are not included, without losing their conservation status of objects corresponding to the Natura 2000 value criteria (third type of areas).

The administrative status (belonging to a protected area) is presently more relevant when valuing a parcel for a given use, due to the very strong use restrictions associated with this protected status, assuming more a societal and economical character than an ecological one.

Another criterion for valuing the conservation aspects is the use of the ERU. The ERU try to portray, as best as the available information allows, the existing and potential resources, allowing an evaluation, for example, of aspects like the naturalness of a given vegetation community (if it corresponds to the ecological characteristics of that site 

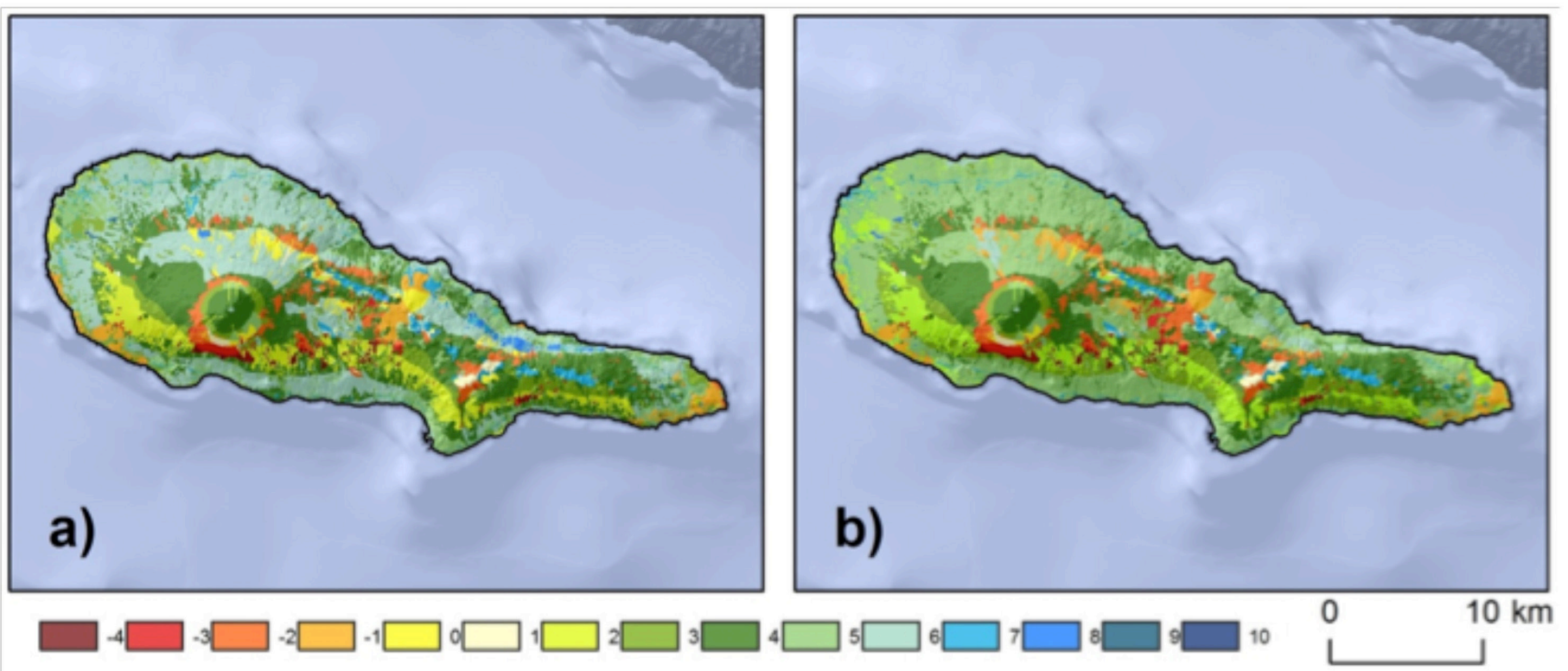

Figure 7. Difference in the conservation value (considering rarity, biodiversity, unique character and naturalness) a); and difference in the protection value (considering the conservation value and the degree of threat) b) between the reference situation and the present land use. Figura 7. Diferenças do valor de conservação (considerando a raridade, biodiversidade, carácter único e naturalidade a) e diferenças do valor de protecção (considerando o valor de conservação e o grau de ameaça) b) entre a situação de referência e o quadro actual de ocupação do solo.

or if it results from any type of disturbance) or its stability according to the deviation degree between the present ecological situation and the situation corresponding to the local stable resources. This last condition is, for example, very significant on the valuation of existing conservation values because it gives an indication on their viability and probable evolution.

The question of being able to identify the viability of an existing value is critical for any conservation policy, because it allows the distinction between values with little maintenance needs (only protection from eventual disturbances), and values whose existence depend on given disturbances, implying the need to evaluate if it is better to invest in that disturbance of a certain value, or invest in the restoration of that value on an adequate site with the adequate resources.

It was therefore in this context, that the valuing process conducted in the scenarios developed in the frame of this research was based on the ILA approach, where there is a clear distinction between what corresponds to the stable resource layer of characterization and what are the conjunctural layers (present land use and management scenarios).

Similar criteria where used to evaluate both layers, when considering, for example, the plant cover (e.g. structural and floristic diversity, rarity of the vegetation communities, naturalness of the formation and resilience), the soil resources (soil agricultural aptitude and risk factors), geology and dynamic processes (runoff, erosion, etc.). This allows the development of the same evaluation procedures to different management scenarios and their comparison in relation to the resources layer (the ERU).

One last remark concerning the valuation process is the development of methods and instruments for a systematic conservation planning and ecosystem-based management in a context of efficient governance. Therefore, the attribution of values has always taken into account this combination of targets, implying that every scenario or evaluation procedure must be soundly explained in terms of the valuing criteria and evaluation perspective applied in that particular case. Also of particular importance is the need to ensure that the process of definition of the valuation criteria is as integrated as possible.

\subsection{The use of the ILA framework in scenario building and evaluation}

This integration is a sine qua non condition for governance, in the sense that it is precisely at this level of attribution of value that the different actors and stakeholders must actively participate. In the context of an island where the value attributed to an object can derive from familiar or social factors established centuries ago and strongly preserved by the isolation (or insularity) assuming a character that outside that context is difficult to understand, this effective involvement is of primary importance.

From the knowledge and consideration of these values, and their integration in the different evaluation and simulation models, depends strongly the success of any systematic conservation planning, aiming at an ecosystem based management integrated in the sustainable development of the island and the quality of living of their inhabitants. As an illustration of the way this process can be conducted, two scenarios were tested, corresponding to the following value factors (Table 1).

In a way to implement systematic conservation planning techniques we used CLUZ (Conservation Land-Use Zoning, 
Table 1. Scenarios considered in the modeling and evaluation processes.

Tabela 1. Cenários considerados nos processos de modelaçâo e avaliaçâo.

\section{Scenario}

1 - Identifying management strategies: investment in restoration, preserving areas of economic significance

\section{Value factors}

Maximization of potential natural formations, conservation value and preservation of the economic value of the main economic activities
2 - Identifying management strategies: investment in restoration, preserving areas of economic significance, considering the different soil aptitudes and the need to safeguard given habitats
Maximization of potential natural formations, conservation value and preservation of the economic value of the main economic activities, introducing a factor of correction of the economic value associated with soil quality and promoting the conservation value of areas associated with wetlands
Smith, 2004) and Marxan (Ball et al., 2009) softwares. In addition to other capabilities, CLUZ is an ArcView GIS interface which acts as a link for the Marxan conservation planning software, and it was in that sense that it was used is this study. Marxan was originally conceived to solve a specific problem referred to as "the minimum set problem", in order to get some minimum representation of biodiversity resources for the lowest possible cost (Possingham el al., 2006). Marxan uses the simulated annealing algorithm, which is a local search algorithm (meta-heuristic) for global optimization problems (Henderson et al., 2003). The spatial optimization process built into Marxan, selects an optimal network of conservation sites that achieves conservation goals, minimizing a set of costs, by estimating, for each planning unit, the external design constraints and thus avoiding costly planning units (Lagrabrielle et al., 2010). For this study, planning units consist of a regular mesh of hexagons, making it easier to combine several types of cost values and better suited for the identification of planning units. The hexagons have an area of $5 \mathrm{ha}$, which is a spatial resolution that adapts well with the conservation features and cost data used.

The portfolio of costs combines three different costs:

- Combined planning unit cost: It is assigned to each planning unit a cost value, based on its area, financial value, the opportunity cost of it being protected (e.g. lost income from farming) or any other relevant factor. Marxan calculates the combined cost of all the planning units in the portfolio.

- Boundary cost: Measures the amount of edge that the planning units in a portfolio share with unprotected units. Thus, a portfolio containing one connected patch of units will have a lower boundary cost than a number of scattered, unconnected units. The length of edge is multiplied by the "boundary length modifier" constant, which is a user-defined number. Increasing the BLM increases the cost of having a fragmented portfolio.

- Species penalty factor (or target penalty cost): It calculates whether the target for each conservation feature is met by a portfolio and includes a cost for any target that has not been met.
Two scenarios were considered. In the first scenario we considered the investment in restoration, preserving areas of economic significance. The scenario was developed considering that the cost corresponded to the conceptual distance between the present vegetation and ecological conditions, and the conditions susceptible of occurring when that area has suffered no disturbances. This cost tries to express the effort needed to achieve the restoration of that vegetation and ecosystems.

As target, two different types of areas were considered: for these areas with low economic value the target was defined as being the difference between the protection value of the ERU and the conservation value of that particular use. For the land uses with a high social value the target considered was the conservation value calculated for that use. The result illustrates a clear differentiation between two types of areas: those clearly targeted as conservation management areas and those where the present land use is considered as having priority over the restoration of the natural vegetation.

Analyzing these results, the relevance of the protection of agricultural areas and the maintenance of the already identified existing values is clear, but they also point to the importance of managing (recover) the areas presently occupied by invasive species and forestation with alien species. This scenario points, therefore, to two types of target management areas: areas already with high conservation value and areas with a land cover of no or with negative ecological value, aiming at the restoration on these areas of the corresponding natural vegetation. Nevertheless, the fact that the target value for the areas with predominant economic value was maintained high, implied that, very important habitats (particularly habitats associated with wetlands) were not included in the target management areas.

In terms of building a management plan, this is not necessarily negative, because these areas are already identified as target areas and because they demand a particular type of management that, although not incompatible with grazing and pastures, implies particular attention to the prevention of the eutrophication of the sink areas, eventually compromising the potential vegetation communities.

In the second scenario we considered the investment in restoration, preserving areas of economic significance 
considering the different soil aptitudes and the need to safeguard given habitats. This essay was carried out integrating a correction of the societal cost through the consideration of the soil aptitude. This was achieved considering that the agricultural areas (pasture, vineyards and other cultures) presented an higher cost if they occupied soils of high quality and a lower one if they occupied soils of low quality, with the exception of the vineyards due to their particularity (cultural landscape of intense work, creating the conditions for vine growth in low quality soils - World Heritage of the Pico Vineyards). The cost for the target habitats corresponded to their Protection Value, while as target the Conservation Value was still the selected criteria.

The results allow us to observe that the main targets resulting from this scenario correspond to the recovery of the Laurisilvae forest and the protection of the wet areas. Again, as already stressed, the valuation of the different types of potential natural vegetation is subjective and can, if altered, lead to somewhat different results. For example, we can clearly observe that the lower value attributed to the scrubland mosaic of Erica azorica and Juniperus brevifolia compared with the high value for Laurisilvae clearly determined the higher importance attributed to the northern side of the Mountain and the Achada Plateau.

Combining these two scenarios different target management areas (Figure 8) were obtained with the following characteristics and management targets:

- Protection of the Pico Mountain, the existing formations of Myrica faya and Erica azorica (scenario 1);

- Protection and/or recovery of the cloud forest and the different wet lands, expanded to all drenched areas (scenario 2);

- Wetlands and protection and/or recovery of Erica azorica communities located in the slope deposits of the Pico Mountain (maximum priority for scenarios 1 and 2 combined);

- As a complementary proprietary management area we must consider the recovery of the areas infested by Pittosporum undulatum;

- The coastal escarpments are also included due to their particular character and sensitivity.

These examples illustrate the way this approach can define management targets and areas for the ensemble of the island based on the integrated landscape characterization system, and using existing and tested methods for the evaluation of areas with more priority for conservation management (like the Marxan approach). These results can be still developed, complementing the Target Management Areas with habitats occupying small patches, where particular values (not only floristic) can occur, and demand, therefore, a multifaceted targeted management approach. These patches are associated with small volcanic formation, wet areas, springs, lakes, deposits and particular geological characteristics.

\section{CONCLUSIONS}

The use of the ILA framework, by allowing the possibility of comparison between the present situation values and

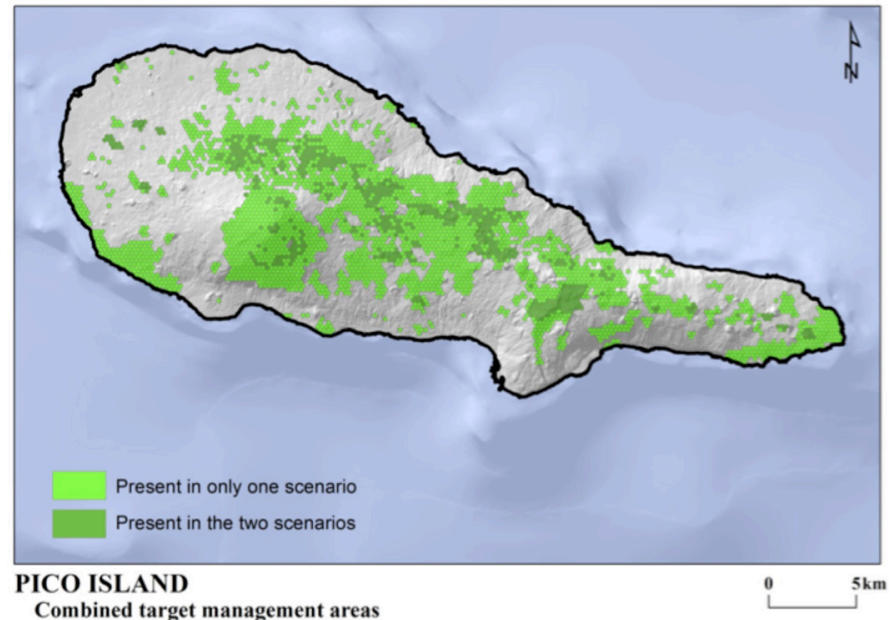

Figure 8. Combined target management areas resulting from scenarios 1 and 2 .

Figura 8. Áreas de gestão prioritárias de acordo com os resultados dos cenários 1 e 2.

constraints, with a stable reference situation, corresponding to the existing stable natural resources, illustrates clearly the management challenges faced in Pico or any other small island.

The scarcity of resources (economical and biogenetical) imposes that the attribution of values must be done according to a multi-dimensional and multi-criteria approach. This is the only way to enable comparative evaluations and decision making within a sound ecosystem-based management aimed at a systematic conservation in the frame of an efficient and functional territorial governance. It also illustrates the need for methodological approaches able to display and evaluate management scenarios in order to fulfill the conditions that Davoudi et al. (2008) consider necessary "to describe, analyze and evaluate territorial governance actions":

- Context: to describe the general structural conditions, features and dynamics of the territory. Describing the favorable territorial preconditions for defining and implementing territorial governance actions (institutional thickness, innovative milieu, territorial capital, etc.);

- Policies: to describe the institutional frameworks of territorial policies, instruments and procedures for governance (i.e. the "governing" of governance);

- Territorial governance actions, defined as the experiences, projects, programs, etc., that need or stimulate a territorial governance approach: to evaluate governance processes and results, at different levels, considering both process criteria and results criteria, and their interaction (does a good process always correspond to a good result?).

Obviously, the presented approach is not the only system of characterization and diagnosis (there were no economic, social and cultural data incorporated and considered in the presented essay with the exception of land use). Nevertheless, 
the methodological framework proved to be a powerful consolidated tool in the evaluation of strengths, weaknesses, opportunities and threats of the biophysical systems and the land use systems, in regard to the natural resources and constraints, and mainly in depicting and justifying these values. These last characteristic is critical for the full involvement of all stakeholders in the governance process.

\section{ACKNOWLEDGMENTS}

This project was developed in the frame of the SMARTPARKS project funded by the Fundação de Ciências e Tecnologia (Portugal) (project PTDC/AAC$\mathrm{AMB} / 098786 / 2008$ ). This research paper was partially developed on the behalf of a Post-Doctoral Research Project (M3.1.7/F/005/2011) lead by A. Gil and supported by the FRC - Regional Fund for Science (Azorean Regional Government).

\section{REFERENCES}

Abdel-Monem, A.; Fernandez, L.A.; Boon, G.A. (1975) $\mathrm{K}-\mathrm{Ar}$ ages from the eastern Azores group (Santa Maria, S. Miguel and the Formigas Islands). Lithos, 8:247-254. DOI: 10.1016/0024-4937(75)90008-0

Ammer, U.; Pröbstl, U.; Mössmer, E.-M. (1986) - Erosion auf Almen. Ein Beitrag zu aktuellen Fragen des Bodenschutzes. Forstwissenschaftliches Centralblatt, 105(1):48-59. DOI: 10.1007/BF02741696

Auxtero, E.; Madeira, M. (2009) - Phosphorus desorbability in soils with andic properties from the Azores, Portugal. Revista de Ciências Agrárias (ISSN 0871-018X), 32(1):423-433, Lisboa, Portugal. Avalilable at http:// www.scielo.oces.mctes.pt/pdf/rca/v32n1/v32n1a37.pdf

Auxtero, E.; Madeira, M.; Sousa, E. (2007) - Predicting the degree of $\mathrm{P}$ saturation of selected Andisols from the Azores (Portugal) by the acidified ammonium oxalate and the Mehlich 3 methods. Revista de Ciências Agrárias (ISSN 0871-018X), 30(2): 314-325, Lisboa, Portugal. Avalilable at http://www.scielo.oces.mctes.pt/pdf/rca/ v30n2/v30n2a23.pdf

Azevedo, J.M.M.; Ferreira, M.R.P. (2006) - The volcanotectonic evolution of Flores Island, Azores (Portugal). Journal of Volcanology and Geothermal Research, 156:90-102. DOI: 10.1016/j.jvolgeores.2006.03.011

Azevedo, J.M.M.; Ferreira, M.P.; Martins, J.A. (1991) - The emergent volcanism of Flores Island, Azores, (Portugal). Arquipélago (ISSN 0870-6581), 9:37-46, Ponta Delgada, Portugal. Available at http://www.horta.uac.pt/intradop/ images/stories/arquipelago/9/Cap5_AZEVEDO-JMM.pdf

Azevedo, E.B.; Pereira, L.S.; Itier, B. (1998) - Modelling the local climate in islands environments. Orographic clouds cover. In: Schemenauer, R.S.; Bridgman, H. (eds.), First International Conference on Fog and Fog Collection, pp.433-443. IDRC, Ottawa. ISBN: 0968388701.

Azevedo, E.B.; Pereira, L.S.; Itier, B. (1999a) - Simulation of local climate in islands environments using a GIS integrated model. In: Musy, A.; Pereira, L.S.; Fritsch, M. (eds.), Emerging technologies for sustainable land use and water management. PPUR, Lausanne. ISBN: 2880744385.
Azevedo, E.B.; Pereira, L.S.; Itier, B. (1999b) - Modelling the local climate in islands environments: water balance applications. Agricultural Water Management, 40(23):393-403. DOI: 10.1016/S0378-3774(99)00012-8

Ball, I.R.; Possingham, H.P.; Watts, M. (2009) - Marxan and relatives: software for spatial conservation prioritization. In: Moilanen, A.; Wilson, K.A.; Possingham, H.P. (eds.), Spatial conservation prioritization: Quantitative methods and computational tools, pp.185-195, Oxford University Press, Oxford, U.K. ISBN: 0199547777.

Bastos, R.; Santos, M.; Ramos, J.A.; Vicente, J.; Guerra, C.; Alonso, J.; Honrado, J.; Ceia, R.S.; Timoteo, S.; Cabral, J.A. (2012) - Testing a novel spatially-explicit dynamic modelling approach in the scope of the laurel forest management for the endangered Azores bullfinch (Pyrrhula murina) conservation. Biological Conservation, 147(1):243-254. DOI: 10.1016/j. biocon.2012.01.009

Borges, P.A.V.; Gabriel, R.; Arroz, A.; Costa, A.; Cunha, R.; Silva, L.; Mendonça, E.; Martins, A.F.; Reis, F.; Cardoso, P. (2010) - The Azorean Biodiversity Portal: an internet database for regional biodiversity outreach. Systematics and Biodiversity, 8(4):423-434. DOI: 10.1080/14772000.2010.514306

Borges, P.A.; Hortal, J. (2009) - Time, area and isolation: factors driving the diversification of Azorean arthropods. Journal of Biogeography, 36(1):178-191. DOI: $10.1111 /$ j.1365-2699.2008.01980.x

Borges, P.A.; Serrano, A.R.; Quartau, J.A. (2000) Ranking the Azorean natural forest reserves for conservation using their endemic arthropods. Journal of Insect Conservation, 4(2):129-147. DOI: 10.1023/A: 1009629012205

Bryan, B.A.; Crossman, N.D.; King, D.; Meyer, W.S. (2011) - Landscape futures analysis: Assessing the impacts of environmental targets under alternative spatial policy options and future scenarios. Environmental Modelling \& Software, 26(1):83-91. DOI: 10.1016/j. envsoft.2010.03.034

Bui, E.N. (2013) - Soil salinity: A neglected factor in plant ecology and biogeography. Journal of Arid Environments, 92:14-25. DOI: 10.1016/j.jaridenv.2012.12.014

Calado, H.; Braga, A.; Moniz, F.; Gil, A.; Vergílio, M. (2013) - Spatial planning and resource use in the Azores. Mitigation and Adaptation Strategies for Global Change, Published Online in November 2013. DOI: 10.1007/ s11027-013-9519-2

Cancela d'Abreu, A.; Moreira, J.M.; Oliveira, M.R. (Coord.) (2005) - Livro das paisagens dos Açores: contributos para a identificação e caracterização das paisagens dos Açores. SRAM/DROTRH, Ponta Delgada. ISBN: 989-2000056.

Capelo, J. (Ed.) (2004) - A paisagem vegetal da Ilha da Madeira. Quercetea (ISSN 0874-5250), 6:3-200, Lisboa, Portugal.

Castellazzi, M.S.; Matthews, J.; Angevin, F.; Sausse, C.; Wood, G.A.; Burgess, P.J.; Brown, I.; Conrad, K.F.; Perry, J.N. (2010) - Simulation scenarios of spatiotemporal arrangement of crops at the landscape scale. Environmental Modelling \& Software, 25(12):1881-1889. DOI: $10.1016 /$ j.envsoft.2010.04.006 
Cienciala, E.; Centeio, A.; Blazek, P.; Soares, M.C.G.; Russ, R. (2013) - Estimation of stem and tree level biomass models for Prosopis juliflora/pallid applicable to multi-stemmed tree species. Trees, 27(4):1061-1070. DOI: $10.1007 / s 00468-013-0857-1$

Connor, S.E.; van Leeuwen, J.F.N.; Rittenour, T.M.; van der Knaap, W.O.; Ammann, B.; Björck, S. (2012) The ecological impact of oceanic island colonization - a palaeoecological perspective from the Azores. Journal of Biogeography, 39(6):1007-1023. DOI: 10.1111/j.13652699.2011.02671.x

Costa, H.; Aranda, S.C.; Lourenco, P.; Medeiros, V.; Azevedo, E.B.; Silva, L. (2012) - Predicting successful replacement of forest invaders by native species using species distribution models: The case of Pittosporum undulatum and Morella faya in the Azores. Forest Ecology and Management, 279:90-96. DOI: 10.1016/j. foreco.2012.05.022

Costa, H.; Bettencourt, M.J.; Silva, C.M.N.; Teodósio, J.; Gil, A.; Silva, L. (2013) - Invasive alien plants in the Azorean protected areas: invasion status and mitigation actions. In: Foxcroft, L.C.; Richardson, D.M.; Pyšek, P.; Genovesi, P. (eds.), Plant invasions in protected areas, pp.375-394, Springer, Dordrecht, Germany. DOI: 10.1007/978-94-007-7750-7_17

Cruz, C.S. (1994) - Consideraçóes relativas à zonagem fitoecológica do Arquipélago da Madeira. In: PintoGomes, C. (ed.), Actas do I Colóquio Internacional de Ecologia da Vegetaçâo, pp.91-113, Universidade de Évora, Evora, Portugal.

Cruz, J.V.; Antunes, P.; Amaral, C.; França, Z.; Nunes, J.C. (2006) - Volcanic lakes of the Azores archipelago (Portugal): Geological setting and geochemical characterization. Journal of Volcanology and Geothermal Research, 156(1-2):135-157. DOI: 10.1016/j. jvolgeores.2006.03.008

Davoudi, S.; Evans, N.; Governa, F.; Santangelo, M. (2008) - Territorial governance in the making. Approaches, methodologies, practices. Boletín de la A.G.E. (ISSN 0212-9426), 46:33-52, Madrid, Spain. Available at http://dialnet.unirioja.es/descarga/articulo/2686504/1. pdf

de Nascimento, L.; Willis, K.J.; Fernández-Palacios, J.M.; Criado, C.; Whittaker, R.J. (2009) - The long-term ecology of the lost forests of La Laguna, Tenerife (Canary Islands). Journal of Biogeography, 36(3):499-514. DOI: 10.1111/j.1365-2699.2008.02012.x

del-Arco, M.J.; Wildpret, W.; Pérez-de-Paz, P.L.; RodríguezDelgado, O.; Acebes, J.R.; García-Gallo, A.; Martín, V.E.; Reyes-Betancourt, J.A.; Salas, M.; Bermejo, J.A.; González, R.; Cabrera, M.V.; García, S. (2006) - Mapa de vegetación de Canarias. Grafcan Ediciones, Santa Cruz de Tenerife, Spain. ISBN: 8461138112

del-Arco, M.J.; Rodríguez-Delgado, O.; Acebes, J.R.; García-Gallo, A.; Pérez-de-Paz, P.L.; González-Mancebo, J.M.; González-González, R.; Garzón-Machado, V. (2009) - Bioclimatology and climatophilous vegetation of Gomera (Canary Islands). Annales Botanici Fennici (ISSN 0003-3847), 46:161-191, Helsinki, Finland. Available at http://www.sekj.org/PDF/anb46-free/ anb46-161.pdf
Dias, E. (2001) - Ecologia e classificação da vegetação natural dos Açores. Cadernos de Botânica 3, Angra do Heroísmo. http://www.angra.uac.pt/GEVA/WEBGEVA/ Publicacoes/phd/PhD.htm

Dias, E.; Mendes, C.; Melo, C.; Pereira, D.; Elias, R. (2005) - Azores central islands vegetation and flora field guide. Quercetea (ISSN 0874-5250), 7:123-173, Lisboa, Portugal.

Dias, N.A.; Matias, L.; Lourenço, N.; Madeira, J.; Carrilho, F.; Gaspar, J.L. (2007) - Crustal seismic velocity structure near Faial and Pico Islands (AZORES), from local earthquake tomography. Tectonophysics, 445(3-4):301317. DOI: $10.1016 /$ j.tecto.2007.09.001

Diniz, A.C.; Matos, G.C. (1986) - Carta da zonagem agro-ecológica e da vegetação de Cabo Verde. I Ilha de Santiago. Garcia de Orta. Série de Botânica (ISSN 03799506), 8(1-2):39-82, Lisboa, Portugal.

Diniz, A.C.; Matos, G.C. (1999) - Carta da zonagem agroecológica e da vegetação de Cabo Verde. X Ilha de Santo Antão. Garcia de Orta. Série de Botânica (ISSN 03799506), 14(2):1:34, Lisboa, Portugal.

Diniz, A.C.; Matos, G.C. (1998) - Zonagem agro-ecológica de Angola (estudo cobrindo $200000 \mathrm{~km}^{2}$ do território). Instituto de Cooperação Portuguesa, Lisboa. ISSN: 0379-9506

Dorman, M.; Svoray, T.; Perevolotsky, A. (2013) Homogenization in forest performance across an environmental gradient - The interplay between rainfall and topographic aspect. Forest Ecology and Management, 310:256-266. DOI: 10.1016/j.foreco.2013.08.026

DROTRH (2008) - PROTA: Plano Regional de Ordenamento do Território da Região Autónoma dos Açores. Direcção Regional de Ordenamento do Território e dos Recursos Hídricos, Secretaria Regional do Ambiente e do Mar, Governo Regional do Açores. Ponta Delgada.

Duarte, M.C.; Rego, F.; Romeiras, M.M.; Moreira, I. (2008) - Plant species richness in the Cape Verde Islands - Eco-geographical determinants. Biodiversity \& Conservation, 17(3):453-466. DOI: 10.1007/s10531007-9226-y

Etherington, T.R.; Holland, E.P. (2013) - Least-cost path length versus accumulated-cost as connectivity measures. Landscape Ecology, 28(7):1223-1229. DOI: 10.1007/ s10980-013-9880-2

Feraud, G.; Kaneoka, I.; Allègre, C.J. (1980) - K/Ar ages and stress pattern in the Azores: geodynamic implications. Earth and Planetary Science Letters, 46(2):275-286. DOI: 10.1016/0012-821X(80)90013-8

Fernandes, J.P. (1993) - ECOGIS/ECOSAD: a methodology for the biophysical environmental assessment within the planning process. Computers, Environment and Urban Systems, 17(4):347-354. DOI: 10.1016/01989715(93)90031-Y

Fernandes, J.P. (2000a) - Landscape ecology and conservation management - evaluation of alternatives in a highway EIA process. Environmental Impact Assessment Review, 20(6):665-680. DOI: 10.1016/S0195-9255(00)00060-3

Fernandes, J.P. (2000b) - Data type and scale effects on an EIA process - context versus object approach: a case study of the evaluation of the impacts of the A2 
road in southern Portugal on the Iberian Lynx. Journal of Environmental Assessment Policy and Management, 2(1):19-41. DOI: 10.1142/S1464333200000047

Fernandes, J.P.; Guiomar, N.; Soares, A.S. (2006) Geometries in landscape ecology. Journal of Mediterranean Ecology (ISSN 1388-7904), 7(1-4):3-13, Urbino, Italy. Available at http://www.jmecology.com/\%5Cpdf\%5C2 006\%5CFernandes3-13.pdf

Fernández-Palacios, J.M.; Andersson, C. (2000) Geographical determinants of the biological richness in the Macaronesian region. Acta Phytogeographica Suecica (ISSN 0084-5914), 85:41-50, Sweden. Available at http://jmferpal.webs.ull.es/other_scientific_papers_files/ APSuecica2000.pdf

Fernández-Palacios, J.M.; de Nascimento, L.; Otto, R.; Delgado, J.D.; García-del-Rey, E.; Arévalo, J.R.; Whittaker, R.J. (2011) - A reconstruction of PalaeoMacaronesia, with particular reference to the long-term biogeography of the Atlantic island laurel forests. Journal of Biogeography, 38(2):226-246. DOI: 10.1111/j.13652699.2010.02427.x

Ferreira, A.B. (2005) - Geodinâmica e perigosidade natural nas ilhas dos Açores. Finisterra (ISSN 0430-5027), 40:103-120, Lisboa, Portugal. Avalilable at http://www. ceg.ul.pt/finisterra/numeros/2005-79/79_09.pdf

Flather, C.H.; Hayward, G.D.; Beissinger, S.R.; Stephens, P.A. (2011) - Minimum viable populations: is there a 'magic number' for conservation practitioners? Trends in Ecology \& Evolution, 26(6):307-316. DOI: 10.1016/j. tree.2011.03.001

Fonseca, G.A.B.; Mittermeier, R.A.; Mittermeier, C.G. (2006) - Conservation of Island biodiversity: importance, challenges and opportunities. 16p., Conservation International, Washington DC.

França, Z.T.M.; Tassinari, C.C.G.; Cruz, J.V.; Aparicio, A.Y.; Araña, V.; Rodrigues, B.N. (2006) - Petrology, geochemistry and $\mathrm{Sr}-\mathrm{Nd}-\mathrm{Pb}$ isotopes of the volcanic rocks from Pico Island-Azores (Portugal). Journal of Volcanology and Geothermal Research, 156(1-2):71-89. DOI: $10.1016 /$ j.jvolgeores.2006.03.013

Furtado, D.S. (1984) - Status e distribuição das plantas vasculares endémicas dos Açores. Arquipélago (ISSN 0870-6581), 5:197-209, Ponta Delgada, Portugal. Available at https://repositorio.uac. $\mathrm{pt} /$ bitstream/10400.3/949/1/Status\%20e\%20 distribui\%C3\%A7\%C3\%A3o\%20das\%20plantas\%20 vasculares $\% 20$ end $\% \mathrm{C} 3 \% \mathrm{~A} 9 \mathrm{micas} \% 20 \mathrm{dos} \% 20$ A\%C3\%A7 ores.pdf

Gil, A.; Calado, H.; Bentz, J. (2011a) - Public participation in municipal transport planning processes - The case of the sustainable mobility plan of Ponta Delgada, Azores, Portugal. Journal of Transport Geography, 19(6):13091319. DOI: 10.1016/j.jtrangeo.2011.06.010

Gil, A.; Calado, H.; Costa, L.T.; Bentz, J.; Fonseca, C.; Lobo, A.; Vergilio, M.; Benedicto, J. (2011b) - A methodological proposal for the development of Natura 2000 sites management plans. Journal of Coastal Research (ISSN 0749-0208), SI64:1326-1330, Szczecin, Poland. Available at http://www.eurosite.org/files/SP64_13261330_A.Gil_.pdf
Gil, A.; Lobo, A.; Abadi, M.; Silva, L.; Calado, H. (2013) Mapping invasive woody plants in Azores protected areas by using very high-resolution multispectral imagery. European Journal of Remote Sensing, 46:289-304. DOI: $10.5721 / \mathrm{EuJRS} 20134616$

Gilpin, M.E.; Soulé, M.E. (1986) - Minimum viable populations: processes of species extinction. Conservation biology: the science of scarcity and diversity. In: Soulé, M.E. (ed.), Conservation biology: the science of scarcity and diversity, pp.19-34, Sinauer Associates, Massachusetts. ISBN: 0878937951.

Henderson, D.; Jacobson, S.H.; Johnson, A.W. (2003) - The theory and practice of simulated annealing. In: Glover, F.; Kochenberger, G.A. (eds.), Handbook of metaheuristics, pp.287-319, Kluwer Academic Publishers, Dordrecht. DOI: $10.1007 / 0-306-48056-5 \_10$

Horn, B.K.P. (1981) - Hill shading and the reflectance map. Proceedings of the IEEE, 69:14-47. DOI: 10.1109/ PROC.1981.11918

Huston, M.A. (1999) - Local processes and regional patterns: Appropriate scales for understanding variation in the diversity of plants and animals. Oikos, 86:393-401. DOI: $10.2307 / 3546645$

Hutchinson, M.F. (1989) - A new procedure for gridding elevation and stream line data with automatic removal of spurious pits. Journal of Hydrology, 106(3-4):211-232. DOI: 10.1016/0022-1694(89)90073-5

Ichter, J.; Evans, D.; Richard, D. (2014) - Terrestrial habitat mapping in Europe: an overview. 152p., European Environment Agency, Luxembourg. ISBN: 9789292134204DOI: $10.2800 / 11055$

Jenson, S.K.; Domingue, J.O. (1988) - Extracting topographic structure from digital elevation data for geographic information system analysis. Photogrammetric Engineering and Remote Sensing, 54(11):1593-1600. DOI: 0099-1112)88/5411-1593\$02.25/0

Kelly, M.; Tuxen, K.A.; Stralberg, D. (2011) - Mapping changes to vegetation pattern in a restoring wetland: Finding pattern metrics that are consistent across spatial scale and time. Ecological Indicators, 11(2):263-273. DOI: $10.1016 /$ j.ecolind.2010.05.003

Lagabrielle, E.; Botta, A.; Daré, W.; David, D.; Aubert, S.; Fabricius, C. (2010) - Modelling with stakeholders to integrate biodiversity into land-use planning - Lessons learned in Réunion Island (Western Indian Ocean). Environmental Modelling \& Software, 25(11):1413-1425. DOI: 10.1016/j.envsoft.2010.01.011

Laliberté, E.; Grace, J.B.; Huston, M.A.; Lambers, H.; Teste, F.P.; Turner, B.L.; Wardle, D.A. (2013) - How does pedogenesis drive plant diversity? Trends in Ecology \& Evolution, 28(6):331-340. DOI: 10.1016/j. tree.2013.02.008

Lamberson, R.H.; Noon, B.R.; Voss, C.; McKelvey, K.S. (1994) - Reserve design for territorial species: the effects of patch size and spacing on the viability of the northern spotted owl. Conservation Biology, 8(1):185-195. DOI: 10.1046/j.1523-1739.1994.08010185.x

Leitão, A.B.; Ahern, J. (2002) - Applying landscape ecological concepts and metrics in sustainable landscape planning. Landscape and Urban Planning, 59(2):65-93. DOI: $10.1016 /$ S0169-2046(02)00005-1 
Lourenço, P.; Medeiros, V.; Gil, A.; Silva, L. (2011) Distribution, habitat and biomass of Pittosporum undulatum, the most important woody plant invader in the Azores Archipelago. Forest Ecology and Management, 262(2):178-187. DOI: 10.1016/j.foreco.2011.03.021

Madeira, J. (1998) - Estudos de neotectónica nas ilhas do Faial, Pico e S. Jorge: Uma contribuição para o conhecimento geodinâmico da junção tripla dos Açores. 481p., PhD dissertation, University of Lisbon. Lisbon, Portugal. Unpublished.

Madeira, J.; Brum da Silveira, A. (2003) - Active tectonics and first paleoseismological results in Faial, Pico and S. Jorge islands (Azores, Portugal). Annals of Geophysics, 46(5):733-761. DOI: 10.4401/ag-3453.

Madeira, M.; Pinheiro, P.; Madruga, J.; Monteiro, F. (2007) - Soils of volcanic systems in Portugal. In: Arnalds, Ó.; Bartoli, F.; Buurman, P.; Óskarsson, H., Stoops, G.; Garcia-Rodeja, E. (eds.), Soils of volcanic regions of Europe, pp.69-81, Springer Verlag, Berlin. DOI: 10.1007/978-3540-48711-1_8

Martín-Martín, C.; Bunce, R.G.H.; Saura, S.; ElenaRosselló, R. (2013) - Changes and interactions between forest landscape connectivity and burnt area in Spain. Ecological Indicators, 33:129-138. DOI: 10.1016/j. ecolind.2013.01.018

Martins, A.M.F. (1993) - The Azores - westernmost Europe: where evolution can be caught red-handed. Boletim do Museu Municipal do Funchal (ISSN 0870-3876), S2:181198, Funchal, Portugal.

Moeslund, J.E.; Arge, L.; Bøcher, P.K.; Dalgaard, T.; Svenning, J.-C. (2013) - Topography as a driver of local terrestrial vascular plant diversity patterns. Nordic Journal of Botany, 31(2):129-144. DOI: 10.1111/j.17561051.2013.00082.x

Moreira, M. (2013) - Valoração da biodiversidade no Parque Natural de Ilha do Pico através da metodologia InVEST. Relatório técnico desenvolvido no âmbito do Projeto SMARTPARKS - Sistema de Ordenamento e Gestáo de Áreas Protegidas em Pequenas Ilhas (PTDC/AACAMB/098786/2008), 37 p., Universidade dos Açores, Ponta Delgada. Unpublished.

Nogué, S.; de Nascimento, L.; Fernández-Palacios, J.M.; Whittaker, R.J.; Willis, K.J. (2013) - The ancient forests of La Gomera, Canary Islands, and their sensitivity to environmental change. Journal of Ecology, 101(2):368377. DOI: $10.1111 / 1365-2745.12051$

Nunes, J.C.C. (1999) - A actividade vulcânica na Ilha do Pico do Plistocénico Superior ao Holocénico: mecanismo eruptivo e hazard vulcânico. 357p., PhD dissertation, University of Azores. Unpublished.

Pinheiro, J.; Madeira, M.; Medina, J.; Sampaio, J.; Madruga, J. (1998) - Andisols of the Azores Archipelago (Portugal). Characteristics and classification. XVI World Congress of Soil Science, Montpellier, France.

Pinheiro, J.; Sampaio, J.; Madruga, J. (1987) - Carta de capacidade de uso do solo da Regiáa Autónoma dos Açores. Departamento de Ciências Agrárias, Universidade dos Açores, Angra do Heroísmo. Unpublished.

Possingham, H.P.; Wilson, K.A.; Andelman, S.J.; Vynne, C.H. (2006) - Protected areas: goals, limitations, and design. In: Groom, M.J.; Meffe, G.K.; Carroll, C.R. (eds.), Principles of conservation biology, $3^{\text {rd }}$ ed., pp.509533, Sinauer Associates Inc., Sunderland. ISBN: 0878935975.

Richard, Y.; Armstrong, D.P. (2010) - Cost distance modelling of landscape connectivity and gap-crossing ability using radio-tracking data. Journal of Applied Ecology, 47(3):603-610. DOI: 10.1111/j.13652664.2010.01806.x

Robertson, P.; Bainbridge, I.; Soye, Y. (2011) - Priorities for conserving biodiversity on European islands. Convention on the conservation of European wildlife and natural habitats. Standing Committee, Strasbourg, France. http://www. ebcd.org/pdf/en/327-Priorities_for_Conserving Biodiversity_on_European_Islands.pdf

Rodríguez-Sánchez, F.; Arroyo, J. (2008) - Reconstructing the demise of Tethyan plants: climate-driven range dynamics of Laurus since the Pliocene. Global Ecology \& Biogeography, 17(6):685-695. DOI: 10.1111/j.14668238.2008.00410.x

Rodríguez-Sánchez, F.; Guzmán, B.; Valido, A.; Vargas, P.; Arroyo, J. (2009) - Late Neogene history of the laurel tree (Laurus L., Lauraceae) based on phylogeographical analyses of Mediterranean and Macaronesian populations. Journal of Biogeography, 36(7):1270-1281. DOI: $10.1111 /$ j.1365-2699.2009.02091.x

Saffache, P.; Angelelli, P. (2010) - Integrated coastal zone management in small islands: A comparative outline of some islands of the Lesser Antilles. Revista de Gestão Costeira Integrada / Journal of Integrated Coastal Zone Management, 10(3):255-279. DOI: 10.5894/rgci228

Santos, C.F.S.; Gomes de Oliveira, A. (2013) - Land use mapping in a protected area of Lagoas de Guarajuba in Camacari, Bahia, Brazil. Revista de Gestâo Costeira Integrada / Journal of Integrated Coastal Zone Management, 13(3):391-397. DOI: $10.5894 /$ rgci396

Saunders, D.A.; Hobbs, R.J.; Margules, C.R. (1991) Biological consequences of ecosystem fragmentation: a review. Conservation Biology, 5(1):18-32. DOI: 10.1111/ j.1523-1739.1991.tb00384.x

Schaefer, H.; Hardy, O.J.; Silva, L.; Barraclough, T.G.; Savolainen, V. (2011) - Testing Darwin's naturalization hypothesis in the Azores. Ecology Letters, 14(4):389-396. DOI: $10.1111 /$ j. $1461-0248.2011 .01600 . x$

Schirone, B.; Ferreira, R.C.; Vessella, F.; Schirone, A.; Piredda, R.; Simeone, M.C. (2010) - Taxus baccata in the Azores: a relict form at risk of imminent extinction. Biodiversity \& Conservation, 19(6):1547-1565. DOI: 10.1007/s10531-010-9786-0

Shaffer, M.L. (1981) - Minimum population sizes for species conservation. BioScience, 31(2):131-134. DOI: $10.2307 / 1308256$

Silva, L.; Smith, C. (2006) - A quantitative approach to the study of non-indigenous plants: an example from the Azores Archipelago. Biodiversity \& Conservation, 15(5):1661-1679. DOI: $10.1007 / \mathrm{s} 10531-004-5015-\mathrm{z}$

Silva, L.; Tavares J. (1997) - Factors affecting Myrica faya Aiton demography in the Azores. Açoreana (ISSN 08740380), 8(3):359-374, Ponta Delgada, Portugal. Available at https://repositorio.uac.pt/bitstream/10400.3/796/1/ Factors $\% 20$ affecting $\% 20$ Myrica $\% 20$ faya $\% 20$ Aiton $\% 20$ demography $\% 20$ in $\% 20$ the $\% 20$ Azores.pdf 
Silveira, P.; Dentinho, T. (2010) - Spatial interaction model of land use - An application to Corvo Island from the 16th, 19th and 20th centuries. Computers, Environment and Urban Systems, 34(2):91-103. DOI: 10.1016/j. compenvurbsys.2009.10.003

Sjögren, E. (2000) - Aspects on the biogeography of Macaronesia from a botanical point of view. Arquipélago (ISSN 0873-4704), S2PA:1-9, Ponta Delgada, Açores, Portugal. Available at http://www.db.uac.pt/pdf/ faunaA/4_aspect.pdf

Smith, R.J. (2004) - Conservation Land-Use Zoning (CLUZ) software. Durrell Institute of Conservation and Ecology, Canterbury. http://anotherbobsmith.files.wordpress. com/2013/03/cluz_guide.pdf

Stephenson, N.L. (1990) - Climatic control of vegetation distribution: the role of water balance. The American Naturalist, 135(5):649-670. DOI: 10.1086/285067

Triantis, K.A.; Borges, P.A.V.; Ladle, R.J.; Hortal, J.; Cardoso, P.; Gaspar, C.; Dinis, F.; Mendonça, E.; Silveira, L.M.A.; Gabriel, R.; Melo, C.; Santos, A.M.C.; Amorim, I.R.; Ribeiro, S.P.; Serrano, A.R.M.; Quartau, J.A.; Whittaker, R.J. (2010) - Extinction debt on oceanic islands. Ecography, 33(2):285-294. DOI: 10.1111/j.16000587.2010.06203.x

Tscharntke, T.; Steffan-Dewenter, I.; Kruess, A.; Thies, C. (2002) - Characteristics of insect populations on habitat fragments: a mini review. Ecological Research, 17(2):229239. DOI: $10.1046 /$ j.1440-1703.2002.00482.x

Vanderpoorten, A.; Rumsey, F.J.; Carine, M.A. (2007) - Does Macaronesia exist? Conflicting signal in the bryophyte and pteridophyte floras. American Journal of Botany, 94(4):625-639. DOI: 10.3732/ajb.94.4.625

Vargas, P. (2007) - Are Macaronesian islands refugia of relict plant lineages?: A molecular survey. In: Weiss, S.; Ferrand, N. (eds.), Phylogeography of Southern European refugia, pp. 297-314, Springer, Netherlands. DOI: 10.1007/14020-4904-8_11
Wahba, G. (1990) - Spline models for observational data. CBMS-NSF Regional Conference Series in Applied Mathematics, Society for Industrial and Applied Mathematics, Philadelphia.

Watts, K.; Handley, P. (2010) - Developing a functional connectivity indicator to detect change in fragmented landscapes. Ecological Indicators, 10(2):552-557. DOI: 10.1016/j.ecolind.2009.07.009

Weigelt, P.; Kreft, H. (2012) - Quantifying island isolation - Insights from global patterns of insular plant species richness. Ecography, 36(4):417-429. DOI: $10.1111 /$ j.1600-0587.2012.07669.x

Wong, P.P.; Marone, E.; Lana, P.; Fortes, M. (coord.) (2005) - Island systems. In: Hassan, R.; Schales, R.; Ash, N. (ed.), Ecosystems and human well-being: current state and trends, pp.663-680, Island Press, Washington DC. ISBN: 1559632275.

Wright, J.P.; Flecker, A.S.; Jones, C.G. (2003) - Local vs. landscape controls on plant species richness in beaver meadows. Ecology, 84(12):3162-3173. DOI: 10.1890/02-0598

Yanes, M.C.M.; Aguilar, M.C.A.; Vernet, J.-L.; Ourcival, J.-M. (1997) - Man and vegetation in northern Tenerife (Canary Islands, Spain), during the prehispanic period based on charcoal analyses. Vegetation History and Archaeobotany, 6(3):187-195. DOI: 10.1007/ BF01372570

Zelený, D.; Li, C.-F.; Chytrý, M. (2010) - Pattern of local plant species richness along a gradient of landscape topographical heterogeneity: result of spatial mass effect or environmental shift? Ecography, 33(3):578-589. DOI: $10.1111 / \mathrm{j} .1600-0587.2009 .05762 . \mathrm{x}$

Zonneveld, I.S. (1989) - The land unit - A fundamental concept in landscape ecology, and its applications. Landscape Ecology, 3(2):67-86. DOI: 10.1007/BF00131171 


\section{APPENDIX 1}

Table 2. Characteristics of the ERUs with an indication of the most frequent land use in each ERU and the most probable type of natural vegetation susceptible of occurring under those ecological conditions.

Tabela 2. Características das UERs com indicação do uso do solo mais frequente em cada UER e o tipo mais provável de vegetação natural suscetivel de ocorrer nessas condiçóes ecológicas.

\begin{tabular}{|c|c|c|c|c|c|c|c|}
\hline \multirow{2}{*}{ ERU } & \multirow{2}{*}{$\begin{array}{l}\text { Morpho-climatic } \\
\text { characteristics }^{1}\end{array}$} & \multicolumn{2}{|c|}{ Geology } & \multicolumn{2}{|c|}{ Soil } & \multirow{2}{*}{ Most probable natural vegetation } & \multirow{2}{*}{$\begin{array}{c}\text { Most } \\
\text { frequent } \\
\text { land use }\end{array}$} \\
\hline & & Formation $^{2}$ & Type $^{3}$ & Class $^{4}$ & Subclass $^{5}$ & & \\
\hline $\mathrm{Aj}$ & Ec & $\mathrm{Td}$ & $\mathrm{V}-\mathrm{Sr}$ & NPA & NPA & $\begin{array}{l}\text { Coastal halophilic and chasmophytic communities of } \\
\text { escarpments and cliffs }\end{array}$ & $\mathrm{Br}$ \\
\hline Ao & $\mathrm{TzL}$ & $\mathrm{Td}$ & $\mathrm{V}-\mathrm{Sr}$ & $\mathrm{IV}+\mathrm{VI}$ & NPA & Myrica faya woodlands & $\mathrm{Ua}$ \\
\hline Ap & $\mathrm{CA}$ & $\mathrm{Td}$ & $\mathrm{V}-\mathrm{Sr}$ & $\mathrm{IV}+\mathrm{VI}$ & NPA & $\begin{array}{l}\text { Transition between halophilic communities and mixed } \\
\text { shrublands of Myrica faya, Juniperus brevifolia and Erica azorica }\end{array}$ & Oc \\
\hline $\mathrm{Bd}$ & $\mathrm{CZ3}$ & $\mathrm{StC}$ & $\mathrm{V}-\mathrm{Sr}$ & VII & $\mathrm{e}, \mathrm{s}$ & $\begin{array}{l}\text { Mosaics of Juniperus brevifolia woodlands and Erica azorica } \\
\text { shrublands }\end{array}$ & $\mathrm{Ohv}$ \\
\hline Bl1 & $P$ & $\mathrm{StC}$ & $\mathrm{V}-\mathrm{Sr}$ & VII & $\mathrm{e}, \mathrm{s}$ & $\begin{array}{l}\text { Deschampsia foliosa grasslands above the timberline with vestigial } \\
\text { patches of Erica azorica shrublands }\end{array}$ & WV \\
\hline $\mathrm{Bl} 2$ & $\mathrm{P}$ & $\mathrm{StC}$ & $\mathrm{V}-\mathrm{Sr}$ & VI & e & $\begin{array}{l}\text { Mosaics of Erica azorica shurblands and Deschampsia foliosa } \\
\text { grasslands }\end{array}$ & $\mathrm{Ea}$ \\
\hline $\mathrm{Bn}$ & V1 & $\mathrm{StC}$ & $\mathrm{V}-\mathrm{Sr}$ & VI & e & $\begin{array}{l}\text { Mixed chasmophytic and riparian vegetation with sparse patches } \\
\text { of Erica azorica }\end{array}$ & $\mathrm{Ea}$ \\
\hline $\mathrm{Cb}$ & $\mathrm{CZ1}$ & $\mathrm{SpC}$ & $\mathrm{Pm}$ & IV & e & "Laurifolia" hydrophil forests & $\mathrm{Cj}$ \\
\hline $\mathrm{Cc}$ & $\mathrm{CZ} 2$ & $\mathrm{SpC}$ & $\mathrm{Pm}$ & IV & e & "Laurifolia" ultra-hygrophil forests & $\mathrm{Cj}$ \\
\hline $\mathrm{Cd}$ & $\mathrm{CZ3}$ & $\mathrm{SpC}$ & $\mathrm{Pm}$ & IV & e & Juniperus brevifolia woodlands & $\mathrm{P}$ \\
\hline $\mathrm{Ce}$ & $\mathrm{CZ} 4$ & $\mathrm{SpC}$ & $\mathrm{Pm}$ & $\mathrm{IV}+\mathrm{III}$ & e & Forest of clouds & $\mathrm{Am}$ \\
\hline $\mathrm{Cf}$ & $\mathrm{CZ5}$ & $\mathrm{SpC}$ & $\mathrm{Pm}$ & IV & e & Juniperus brevifolia woodlands & $\mathrm{Ea}$ \\
\hline $\mathrm{Cg}$ & $\mathrm{CZ6}$ & $\mathrm{SpC}$ & $\mathrm{Pm}$ & IV & e & Mixed shrublands of Juniperus brevifolia and Erica azorica & $\mathrm{P}$ \\
\hline $\mathrm{Ch}$ & $\mathrm{CZ7}$ & $\mathrm{SpC}$ & $\mathrm{Pm}$ & $\mathrm{V}$ & e & "Laurifolia" mesic forests & $\mathrm{Ea}$ \\
\hline $\mathrm{Ci}$ & $\mathrm{CZ8}$ & $\mathrm{SpC}$ & $\mathrm{Pm}$ & III & e & "Laurifolia" mesic forests & $\mathrm{Am}$ \\
\hline $\mathrm{Ck}$ & $\mathrm{L}$ & $\mathrm{SpC}$ & $\mathrm{Pm}$ & $\mathrm{V}$ & e & Plant communities of oligotrophic lagoons & $\mathrm{L}$ \\
\hline $\mathrm{Cm}$ & $\mathrm{Pb}$ & $\mathrm{SpC}$ & Pm & $\mathrm{VI}$ & e & Plant communities of ombrotrophic peat bogs & $\mathrm{Pb}$ \\
\hline Co & TzL & $\mathrm{SpC}$ & $\mathrm{Pm}$ & NPA & NPA & Myrica faya woodlands & Oc \\
\hline $\mathrm{Cp}$ & $\mathrm{CA}$ & $\mathrm{SpC}$ & $\mathrm{Pm}$ & NPA & NPA & $\begin{array}{l}\text { Transition between halophilic communities and mixed } \\
\text { shrublands of Myrica faya, Juniperus brevifolia and Erica azorica }\end{array}$ & $\mathrm{Ua}$ \\
\hline $\mathrm{Cq}$ & M & $\mathrm{SpC}$ & $\mathrm{Pm}$ & $\mathrm{V}$ & e & Paludal communities and/or Juniperus brevifolia woodlands & $\mathrm{Cj}$ \\
\hline $\mathrm{Db}$ & $\mathrm{CZ1}$ & $\mathrm{CC}$ & $\mathrm{Pm}$ & IV & e & $\begin{array}{l}\text { Mosaics of "Laurifolia" hydrophil forests and mixed shrublands } \\
\text { on volcanic sands }\end{array}$ & $\mathrm{Cj}$ \\
\hline Dc & CZ2 & $\mathrm{CC}$ & $\mathrm{Pm}$ & V & - & $\begin{array}{l}\text { Mosaics of "Laurifolia" ultra-hygrophil forests and mixed } \\
\text { shrublands on volcanic sands }\end{array}$ & $\mathrm{Cj}$ \\
\hline $\mathrm{Dd}$ & CZ3 & CC & $\mathrm{Pm}$ & $\mathrm{V}+\mathrm{VI}$ & e & $\begin{array}{l}\text { Mosaics of Juniperus brevifolia woodlands and mixed shrublands } \\
\text { on volcanic sands }\end{array}$ & $\mathrm{Ea}$ \\
\hline De & $\mathrm{CZ} 4$ & $\mathrm{CC}$ & $\mathrm{Pm}$ & $\mathrm{V}$ & e & Forest of clouds and mixed shrublands on volcanic sands & $\mathrm{Ea}$ \\
\hline Df & CZ5 & $\mathrm{CC}$ & $\mathrm{Pm}$ & $\mathrm{V}+\mathrm{VI}$ & e & $\begin{array}{l}\text { Mosaics of Juniperus brevifolia woodlands and mixed shrublands } \\
\text { on volcanic sands }\end{array}$ & $\mathrm{Ea}$ \\
\hline Dg & CZ6 & $\mathrm{CC}$ & $\mathrm{Pm}$ & $\mathrm{IV}+\mathrm{VI}$ & - & $\begin{array}{l}\text { Mixed shrublands of Juniperus brevifolia, Erica azorica and other } \\
\text { shrubs on volcanic sands }\end{array}$ & $\mathrm{Cj}$ \\
\hline $\mathrm{Dh}$ & CZ7 & $\mathrm{CC}$ & $\mathrm{Pm}$ & $\mathrm{V}$ & e & $\begin{array}{l}\text { Mosaics of "Laurifolia" mesic forests and mixed shrublands on } \\
\text { volcanic sands }\end{array}$ & $\mathrm{Cj}$ \\
\hline
\end{tabular}


Fernandes et al.

Revista de Gestão Costeira Integrada / Journal of Integrated Coastal Zone Management 14(2):243-266 (2014)

\begin{tabular}{|c|c|c|c|c|c|c|c|}
\hline $\mathrm{Di}$ & $\mathrm{CZ8}$ & $\mathrm{CC}$ & $\mathrm{Pm}$ & IV & e & $\begin{array}{l}\text { Mosaics of "Laurifolia" mesic forests and mixed shrublands on } \\
\text { volcanic sands }\end{array}$ & Am \\
\hline $\mathrm{Dj}$ & Ec & $\mathrm{CC}$ & $\mathrm{Pm}$ & NPA & NPA & $\begin{array}{l}\text { Coastal halophilic and chasmophytic communities of } \\
\text { escarpments and cliffs }\end{array}$ & $\mathrm{Br}$ \\
\hline $\mathrm{Dk}$ & $\mathrm{L}$ & $\mathrm{CC}$ & $\mathrm{Pm}$ & VI & e & Plant communities of oligotrophic lagoons & $\mathrm{L}$ \\
\hline $\mathrm{Dl}$ & $\mathrm{P}$ & $\mathrm{CC}$ & $\mathrm{Pm}$ & $\mathrm{V}+\mathrm{VI}$ & e & $\begin{array}{l}\text { Mosaics of Erica azorica shurblands, Deschampsia foliosa } \\
\text { grasslands and other shrubs on volcanic sands }\end{array}$ & $\mathrm{Ea}$ \\
\hline $\mathrm{Dm}$ & $\mathrm{Pb}$ & $\mathrm{CC}$ & $\mathrm{Pm}$ & VI & e & Plant communities of ombrotrophic peat bogs & $\mathrm{Pb}$ \\
\hline Do & TzL & $\mathrm{CC}$ & $\mathrm{Pm}$ & III & - & Myrica faya woodlands or mixed shrublands on volcanic sands & $\mathrm{Ua}$ \\
\hline $\mathrm{Dp}$ & $\mathrm{CA}$ & $\mathrm{CC}$ & $\mathrm{Pm}$ & $\mathrm{IV}+\mathrm{VI}$ & e & $\begin{array}{l}\text { Mosaics of halophilic communities and mixed shrublands on } \\
\text { volcanic sands }\end{array}$ & $\mathrm{Pu}$ \\
\hline $\mathrm{Dq}$ & M & $\mathrm{CC}$ & $\mathrm{Pm}$ & $\mathrm{V}$ & - & $\begin{array}{l}\text { Paludal communities and/or mosaics of Juniperus brevifolia } \\
\text { woodlands and mixed shrublands on volcanic sands }\end{array}$ & Am \\
\hline $\mathrm{Ee}$ & CZ4 & $\mathrm{Pa}-\mathrm{ML}$ & $\mathrm{Vr}$ & $\mathrm{V}+\mathrm{VI}$ & - & Forest of clouds & Am \\
\hline $\mathrm{Ei}$ & CZ8 & $\mathrm{Pa}-\mathrm{ML}$ & $\mathrm{Vr}$ & $\mathrm{VI}+\mathrm{VII}$ & - & "Laurifolia" mesic forests & Am \\
\hline $\mathrm{Fi}$ & $\mathrm{CZ8}$ & Pa-MP & $\mathrm{Vr}$ & $\mathrm{VI}+\mathrm{IV}$ & s & "Laurifolia" mesic forests & $\mathrm{Pu}$ \\
\hline $\mathrm{Fj}$ & Ec & Pa-MP & $\mathrm{Vr}$ & $\mathrm{NPA}$ & NPA & $\begin{array}{l}\text { Coastal halophilic and chasmophytic communities of } \\
\text { escarpments and cliffs }\end{array}$ & $\mathrm{Br}$ \\
\hline Fo & $\mathrm{TzL}$ & Pa-MP & $\mathrm{Vr}$ & NPA & NPA & Myrica faya woodlands & $\mathrm{Pu}$ \\
\hline $\mathrm{Fp}$ & $\mathrm{CA}$ & Pa-MP & $\mathrm{Vr}$ & NPA & NPA & $\begin{array}{l}\text { Transition between halophilic communities and mixed } \\
\text { shrublands of Myrica faya, Juniperus brevifolia and Erica azorica }\end{array}$ & $\mathrm{Pu}$ \\
\hline Ge & CZ4 & $\mathrm{Pa}$ & $\mathrm{Vr}$ & $\mathrm{VI}$ & e & Forest of clouds & $\mathrm{Cj}$ \\
\hline Gg & CZ6 & $\mathrm{Pa}$ & $\mathrm{Vr}$ & $\mathrm{VI}$ & e & Mixed shrublands of Juniperus brevifolia and Erica azorica & $\mathrm{Cj}$ \\
\hline Gh & $\mathrm{CZ7}$ & $\mathrm{Pa}$ & $\mathrm{Vr}$ & $\mathrm{V}+\mathrm{VI}$ & e & "Laurifolia" mesic forests & $\mathrm{P}$ \\
\hline $\mathrm{Gi}$ & CZ8 & $\mathrm{Pa}$ & $\mathrm{Vr}$ & $\mathrm{V}+\mathrm{VI}$ & e & "Laurifolia" mesic forests & $\mathrm{Cj}$ \\
\hline $\mathrm{Gj}$ & $\mathrm{Ec}$ & $\mathrm{Pa}$ & $\mathrm{Vr}$ & $\mathrm{III}+\mathrm{IV}$ & e & $\begin{array}{l}\text { Coastal halophilic and chasmophytic communities of } \\
\text { escarpments and cliffs }\end{array}$ & $\mathrm{Br}$ \\
\hline Gk & $\mathrm{L}$ & $\mathrm{Pa}$ & $\mathrm{Vr}$ & $\mathrm{VI}$ & $\mathrm{w}$ & Plant communities of oligotrophic lagoons & $\mathrm{L}$ \\
\hline Gn & $\mathrm{V} 2$ & $\mathrm{~Pa}$ & $\mathrm{Vr}$ & NPA & NPA & Mixed chasmophytic and riparian vegetation & $\mathrm{Ua}$ \\
\hline Go & $\mathrm{TzL}$ & $\mathrm{Pa}$ & $\mathrm{Vr}$ & NPA & NPA & Myrica faya woodlands & $\mathrm{Ua}$ \\
\hline Gp & $\mathrm{CA}$ & $\mathrm{Pa}$ & $\mathrm{Vr}$ & NPA & NPA & $\begin{array}{l}\text { Transition between halophilic communities and mixed } \\
\text { shrublands of Myrica faya, Juniperus brevifolia and Erica azorica }\end{array}$ & $\mathrm{Ua}$ \\
\hline Gq & M & $\mathrm{Pa}$ & $\mathrm{Vr}$ & $\mathrm{V}+\mathrm{VI}$ & e & Paludal communities and/or Juniperus brevifolia woodlands & $\mathrm{P}$ \\
\hline $\mathrm{He}$ & CZ4 & $\mathrm{A}, \mathrm{Pa}$ & $\mathrm{Vr}$ & $\mathrm{VI}$ & s & Forest of clouds & $\mathrm{Ea}$ \\
\hline $\mathrm{Hl}$ & $\mathrm{P}$ & $\mathrm{A}, \mathrm{Pa}$ & $\mathrm{Vr}$ & $\mathrm{VII}+\mathrm{VI}$ & s & $\begin{array}{l}\text { Mosaics of Erica azorica shurblands and Deschampsia foliosa } \\
\text { grasslands }\end{array}$ & $\mathrm{P}$ \\
\hline $\mathrm{Ib}$ & $\mathrm{CZ1}$ & $\mathrm{B} 1$ & $\mathrm{Vr}$ & $\mathrm{V}$ & e & $\begin{array}{l}\text { "Laurifolia" hydrophil forests with important patches of Erica } \\
\text { azorica shrublands }\end{array}$ & $\mathrm{Cj}$ \\
\hline Ic & $\mathrm{CZ} 2$ & $\mathrm{~B} 1$ & $\mathrm{Vr}$ & $\mathrm{VI}+\mathrm{VII}$ & s & $\begin{array}{l}\text { "Laurifolia" ultra-hygrophil forests with important patches of } \\
\text { Erica azorica shrublands }\end{array}$ & $\mathrm{Ea}$ \\
\hline Id & $\mathrm{CZ3}$ & $\mathrm{B} 1$ & $\mathrm{Vr}$ & $\mathrm{V}+\mathrm{VI}$ & e & $\begin{array}{l}\text { Juniperus brevifolia woodlands with important patches of Erica } \\
\text { azorica shrublands }\end{array}$ & $\mathrm{Cj}$ \\
\hline Ie & CZ4 & B1 & $\mathrm{Vr}$ & IV+III & e & $\begin{array}{l}\text { Forest of clouds with important patches of Erica } \\
\text { azorica shrublands }\end{array}$ & $\mathrm{Am}$ \\
\hline $\operatorname{Ig}$ & CZ6 & B1 & $\mathrm{Vr}$ & $\mathrm{V}+\mathrm{VI}$ & s & $\begin{array}{l}\text { Mixed shrublands of Juniperus brevifolia and Erica } \\
\text { azorica }\end{array}$ & $\mathrm{Ea}$ \\
\hline Ii & CZ8 & B1 & $\mathrm{Vr}$ & IV+III & e & $\begin{array}{l}\text { "Laurifolia" mesic forests with important patches of } \\
\text { Erica azorica shrublands }\end{array}$ & Am \\
\hline
\end{tabular}


Fernandes et al.

Revista de Gestão Costeira Integrada / Journal of Integrated Coastal Zone Management 14(2):243-266 (2014)

\begin{tabular}{|c|c|c|c|c|c|c|c|}
\hline $\mathrm{Ij}$ & Ec & B1 & $\mathrm{Vr}$ & NPA & NPA & $\begin{array}{l}\text { Coastal halophilic and chasmophytic communities } \\
\text { of escarpments and cliffs }\end{array}$ & $\mathrm{Br}$ \\
\hline In & $\mathrm{V} 2$ & $\mathrm{~B} 1$ & $\mathrm{Vr}$ & VI & e & Mixed chasmophytic and riparian vegetation & $\mathrm{Ea}$ \\
\hline Io & $\mathrm{TzL}$ & $\mathrm{B} 1$ & $\mathrm{Vr}$ & NPA & NPA & $\begin{array}{l}\text { Myrica faya woodlands or mixed shrublands of Myrica faya and } \\
\text { Juniperus brevifolia }\end{array}$ & Am \\
\hline Ip & $\mathrm{CA}$ & B1 & $\mathrm{Vr}$ & NPA & NPA & $\begin{array}{l}\text { Mosaics of halophilic communities and mixed shrublands of } \\
\text { Myrica faya and Juniperus brevifolia }\end{array}$ & $\mathrm{Ua}$ \\
\hline $\mathrm{Iq}$ & M & $\mathrm{B} 1$ & $\mathrm{Vr}$ & $\mathrm{VI}+\mathrm{VII}$ & s & Paludal communities and/or Juniperus brevifolia woodlands & $\mathrm{Ea}$ \\
\hline Jh & $\mathrm{CZ7}$ & Pb-at & $\mathrm{Vr}$ & $\mathrm{V}$ & e & "Laurifolia" mesic forests & $\mathrm{P}$ \\
\hline Ji & CZ8 & Pb-at & $\mathrm{Vr}$ & NPA & NPA & "Laurifolia" mesic forests & $\mathrm{Ua}$ \\
\hline $\mathrm{Jj}$ & Ec & Pb-at & $\mathrm{Vr}$ & NPA & NPA & $\begin{array}{l}\text { Coastal halophilic and chasmophytic communities of } \\
\text { escarpments and cliffs }\end{array}$ & $\mathrm{Br}$ \\
\hline Jo & $\mathrm{TzL}$ & $\mathrm{Pb}$-at & $\mathrm{Vr}$ & NPA & NPA & Myrica faya woodlands & Ua \\
\hline $\mathrm{Jp}$ & $\mathrm{CA}$ & $\mathrm{Pb}$-at & $\mathrm{Vr}$ & NPA & NPA & $\begin{array}{l}\text { Transition between halophilic communities and mixed } \\
\text { shrublands of Myrica faya, Juniperus brevifolia and Erica azorica }\end{array}$ & $\mathrm{Ua}$ \\
\hline Jq & M & $\mathrm{Pb}$-at & $\mathrm{Vr}$ & $\mathrm{V}$ & s & Paludal communities and/or Juniperus brevifolia woodlands & $\mathrm{P}$ \\
\hline $\mathrm{Kb}$ & $\mathrm{CZ1}$ & B & $\mathrm{Vr}$ & IV & - & "Laurifolia" hydrophil forests & $\mathrm{Cj}$ \\
\hline Kc & $\mathrm{CZ2}$ & B & $\mathrm{Vr}$ & $\mathrm{V}$ & - & "Laurifolia" ultra-hygrophil forests & $\mathrm{Cj}$ \\
\hline Kd & $\mathrm{CZ3}$ & $\mathrm{B}$ & $\mathrm{Vr}$ & IV & - & Juniperus brevifolia woodlands & $\mathrm{Cj}$ \\
\hline $\mathrm{Ke}$ & CZ4 & $\mathrm{B}$ & $\mathrm{Vr}$ & $\mathrm{III}+\mathrm{IV}$ & - & Forest of clouds & Am \\
\hline Kf & $\mathrm{CZ5}$ & $\mathrm{B}$ & $\mathrm{Vr}$ & $\mathrm{V}$ & e & Juniperus brevifolia woodlands & $\mathrm{Cj}$ \\
\hline $\mathrm{Kg}$ & CZ6 & B & $\mathrm{Vr}$ & IV & - & Mixed shrublands of Juniperus brevifolia and Erica azorica & $\mathrm{Am}$ \\
\hline $\mathrm{Kh}$ & $\mathrm{CZ7}$ & $\mathrm{B}$ & $\operatorname{Vr}$ & $\mathrm{V}$ & e & "Laurifolia" mesic forests & $\mathrm{Cj}$ \\
\hline $\mathrm{Ki}$ & CZ8 & B & $\mathrm{Vr}$ & NPA & NPA & "Laurifolia" mesic forests & $\mathrm{Am}$ \\
\hline $\mathrm{Kj}$ & $\mathrm{Ec}$ & $\mathrm{B}$ & $\mathrm{Vr}$ & NPA & NPA & $\begin{array}{l}\text { Coastal halophilic and chasmophytic communities of } \\
\text { escarpments and cliffs }\end{array}$ & $\mathrm{Br}$ \\
\hline $\mathrm{Kk}$ & $\mathrm{L}$ & $\mathrm{B}$ & $\operatorname{Vr}$ & $\mathrm{V}$ & e & Plant communities of oligotrophic lagoons & $\mathrm{L}$ \\
\hline Kl1 & $\mathrm{P}$ & $\mathrm{B}$ & $\mathrm{Vr}$ & VII & $\mathrm{e}, \mathrm{s}$ & Deschampsia foliosa grasslands above the timberline & WV \\
\hline $\mathrm{K} 12$ & $\mathrm{P}$ & $\mathrm{B}$ & $\mathrm{Vr}$ & VI & e & $\begin{array}{l}\text { Mosaics of Erica azorica shurblands and Deschampsia foliosa } \\
\text { grasslands above the timberline }\end{array}$ & $\mathrm{Ohv}$ \\
\hline $\mathrm{K} 13$ & $\mathrm{P}$ & $\mathrm{B}$ & $\mathrm{Vr}$ & $\mathrm{V}+\mathrm{VI}$ & e & $\begin{array}{l}\text { Mosaics of Erica azorica shurblands and Deschampsia foliosa } \\
\text { grasslands }\end{array}$ & $\mathrm{Ea}$ \\
\hline $\mathrm{Kn}$ & $\mathrm{V} 2$ & $\mathrm{~B}$ & $\mathrm{Vr}$ & NPA & NPA & Mixed chasmophytic and riparian vegetation & Am \\
\hline Ko & $\mathrm{TzL}$ & $\mathrm{B}$ & $\mathrm{Vr}$ & NPA & NPA & Myrica faya woodlands & Am \\
\hline Kp & $\mathrm{CA}$ & $\mathrm{B}$ & $\mathrm{Vr}$ & NPA & NPA & $\begin{array}{l}\text { Transition between halophilic communities and mixed } \\
\text { shrublands of Myrica faya, Juniperus brevifolia and Erica azorica }\end{array}$ & $\mathrm{Ua}$ \\
\hline $\mathrm{Kq}$ & M & $\mathrm{B}$ & $\mathrm{Vr}$ & $\mathrm{IV}+\mathrm{VI}$ & - & Paludal communities and/or Juniperus brevifolia woodlands & Am \\
\hline
\end{tabular}

${ }^{1} \mathrm{CA}$ : Coastal areas; M: Marshes; Ec: Escarpments and cliffs; TzL: Transition zones and lowlands Pb: Peat bogs; L: Lagoons; V1: Valleys with LS factor > 500; V1: Valleys with LS factor > 500 and < 50m wide; P: Pico; CZ1: Climatic zone 1 (P: h, M: h, W: h); CZ2: Climatic zone 2 (P: h, M: h, W: m); CZ3: Climatic zone 3 (P: h, M: m, W: h); CZ4: Climatic zone 4 (P: h, M: m, W: m); CZ5: Climatic zone 5 (P: m, M: h, W: h); CZ6: Climatic zone 6 (P: m, M: m, W: h); CZ7: Climatic zone 7 (P: m, M: h, W: m); CZ8: Climatic zone 8 (P: m, M: m, W: m) (P: Precipitation; M: Moisture; W: Wind; h: high; m: moderate)

${ }^{2}$ B: Basalts; Pa: Peridotic andesites; B1: Basalts from the historic eruptions of the $15^{\text {th }}$ and $18^{\text {th }}$ centuries; A: Andesites; Pa-ML: Peridotic andesites from "Mistério de Sta Luzia"; Pa-MP: Peridotic andesites from "Mistério da Prainha"; CC: Cinder cones; Pb-at: Peridotic basalts of andesitic trend; Td: Torrential dejections; SpC: Spatter cones; StC: Stratocone

${ }^{3}$ Vr: Volcanic rocks; Pm: Pyroclastic materials; V-Sr: Volcano-sedimentary rocks

${ }^{2}$ I to VII; NPA - Non-productive areas (urban areas, infrastructures and bare rocks)

${ }^{5}$ e: soils with high susceptibility to erosion; s: soil limitation at the level of the roots; w: soil with excess water (drenching); NPA - Non-productive areas (urban areas, infrastructures and bare rocks ${ }^{6}$ Am: Acacia melanoxylon stands; Cj: Cryptomeria japonica stands; Ea: Erica azorica shrublands; Pu: Pittosporum undulatum communities Ohv: Other herbaceous vegetation; Ua: Urban areas; Oc: Other crops; Br: Bare rocks; P: Pastures; L: Lagoons; Pb: Peat bogs; WV: Open spaces without vegetation 